\title{
P-11 FACILITY CLEANUP SUMMARY REPORT
}

\author{
M. N. Raile \\ Development Engineering Department \\ Research and Engineering Division
}

December 1974
ATLANTIC RICHFIELD HANFORD COMPANY RICHLAND, WASHINGTON
Operated for the U.S. Atomic Energy Commission by Atlantic Richfield Hanford Company Under Contract AT-(45-1)-2130




\section{DISCLAIMER}

This report was prepared as an account of work sponsored by an agency of the United States Government. Neither the United States Government nor any agency Thereof, nor any of their employees, makes any warranty, express or implied, or assumes any legal liability or responsibility for the accuracy, completeness, or usefulness of any information, apparatus, product, or process disclosed, or represents that its use would not infringe privately owned rights. Reference herein to any specific commercial product, process, or service by trade name, trademark, manufacturer, or otherwise does not necessarily constitute or imply its endorsement, recommendation, or favoring by the United States Government or any agency thereof. The views and opinions of authors expressed herein do not necessarily state or reflect those of the United States Government or any agency thereof. 


\section{DISCLAIMER}

Portions of this document may be illegible in electronic image products. Images are produced from the best available original document. 


\section{TABLE OF CONTENTS}

Page

INTRODUCTION . . . . . . . . . . . . . . . . . . . . . 1

OBJECTIVES . . . . . . . . . . . . . . . . . . . . . . 1

SUMMARY. . . . . . . . . . . . . . . . . . . . . 1

HISTORY. . . . . . . . . . . . . . . . . . . . . . 2

DISCUSSION . . . . . . . . . . . . . . . . . . . 2

WORK AUTHORIZATION . . . . . . . . . . . . . . . 2

WORK PLANS AND PROCEDURES. . . . . . . . . . . . . . . 5

ORGANIZATION . . . . . . . . . . . . . . . . . . . 7

AUXILIARY EQUIPMENT DESCRIPTION. . . . . . . . . . . . . . 7

DEMOLITION AND REMOVAL . . . . . . . . . . . . . . . 11

SITE RESTORATION AND RELEASE . . . . . . . . . . . . . 30

COST ANALYSIS. . . . . . . . . . . . . . . . . . . 30

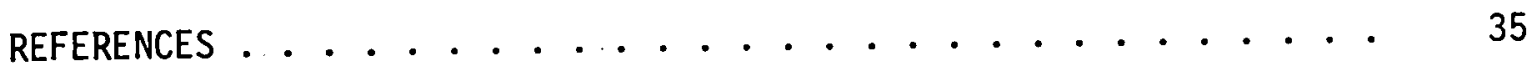

ACKNOWLEDGMENTS. . . . . . . . . . . . . . . . . . . 35

APPENDIX . . . . . . . . . . . . . . . . . . 37 


\section{ABSTRACT}

This document describes methods, techniques, and equipment employed at Hanford for the cleanup, dismantling, and decommissioning of plutoniumcontaminated facilities. 


\section{P-11 FACILITY CLEANUP SUMMARY REPORT}

\section{INTRODUCTION}

This report summarizes methods and techniques employed for the cleanup of the plutonium-contaminated P-11 Facility accomplished during fiscal years 1974 and 1975, with physical completion achieved on 0ctober 16, 1974. Details of the exact scope of the work involved, responsibilities, plans, procedures, and techniques are covered for possible application on other Atomic Energy Commission programs of environmental concern.

\section{OBJECTIVES}

The objectives of the P-11 Facility cleanup program were to restore the area to $i$ ts natural state so that it would not pose an environmental hazard to people or animals and to allow alternative uses of the land area, if so desired. The following criteria were used as the basis for achieving these objectives:

- Conditional public access or use of the cleaned area shall not result in any risk to human health and welfare from radioactive materials.

- There shall be no radiation exposure above and beyond the natural background exposure.

- Potential harmful effects to the biota from radioactivity shall be eliminated.

- Airborne contamination, and subsequent migration of radioactive material in the event of a range fire or other natural phenomena shall be el iminated.

- The removed radioactive material shall be stored and controlled at a minimum of cost and surveillance.

\section{SUMMARY}

Demolition and removal work to clean up the P-11 Facility was started on April 4, 1974, with site preparation and the addition of an airlock and ventilation exhauster to the 120 Building for contamination control. Removal of the plutonium-contaminated 120 Building, auxiliaries, and waste crib was completed on October 16, 1974. Final site restoration, seeding, and removal of auxiliary services and structures was completed on November 19,1974 . As a result of the cleanup activity, potential airborne contamination and migration of radioactive particulates were eliminated. The radioactively-contaminated materials exceeding the minimum transuranic concentration of ten nanocuries per gram, as provided by Atomic Energy Commission policy guidelines, were sealed in approved containers for 20-year retrievable storage. Although a total of six weeks lost time resulted from two separate construction craft strikes, the cleanup work was completed within two weeks of original schedule and at a cost of approximately $\$ 265,000$. No major injuries or contamination to 
personnel or environs occurred during the course of the cleanup work. The prime objectives of the decommissioning program were achieved in total with considerable knowledge gained in plutonium contamination control, demolition methods, and special work techniques.

\section{HISTORY}

The P-11 Facility, which served as a laboratory for plutonium criticality studies prior to 1952, consisted of two major buildings: the 123 Building (a converted residence) and the 120 Building. The 123 Building, which served as the control house, had been previousily razed. No plutonium contamination was involved in that work. The 120 Building, which was a single story metal building about 32 feet by 42 feet in plan contained the critical assembly room, a small chemistry laboratory, storage and tank room, and a change room. Drain lines from the building and process equipment were routed to an underground waste crib for retention of any disposed radioactive nuclides in the soil. A plan drawing of the 120 Building, H-7-692, is included in the Appendix Section as Attachment "A".

On November 16, 1951, a critical excursion resulted in extensive plutonium contamination to the interior of the 120 Building. On December 4, 1951, during the final stages of decontamination work to reactivate the facility, a fire broke out in the southwest part of the building apparently from spontaneous ignition of decontamination materials. The fire gutted the storage room and chemistry laboratory, burned through the ceiling, melted the aluminum filter ducts, and set fire to the exhaust filters (Figure 1). Contamination was extensive in this area and throughout the attic after the vent system was breached. Because connecting doors were open, contamination also spread to other parts of the building, particularly to the process rooms. The spread of contamination was augmented by fire control measures, resulting in radioactive particulates being washed to the outside of the building along the foundation and door thresholds. The contamination was fixed using sealants and concrete grout and the 120 Building sealed off and abandoned in consideration of the high risk and cost to decontaminate and restore the facility for continued criticality studies. A complete description of the P-ll Facilities, equipment, and experiments performed is provided in the criticality study document. ${ }^{1}$ The P-11 Facility 120 Building and site with power, office building and clothing trailer installed, and prior to start of any demolition work, is shown in Figure 2. The pipe in right foreground is the waste crib vent.

\section{DISCUSSION}

\section{WORK AUTHORIZATION}

A survey of the P-11 Facility and site for the purpose of demolition and estimating cost was initiated by Battelle Northwest in April 1970. The demolition work proposed was not authorized at that time because of the lack of necessary funds. A joint study of all facilities to be decommissioned was prepared in June 1973, by the Atlantic Richfield Hanford 


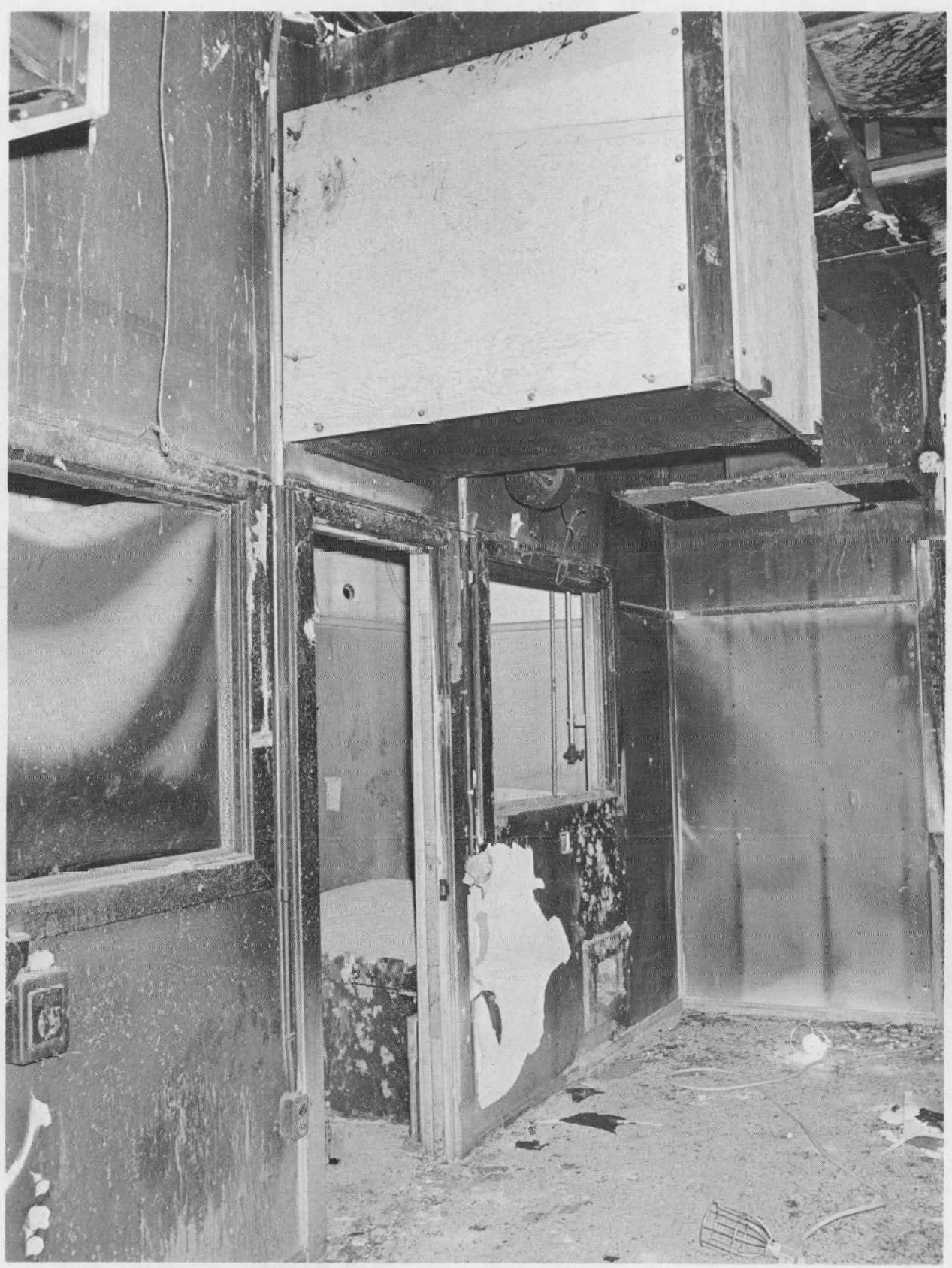

FIGURE 1

BURNED-OUT SECTION OF 120 BUILDING 


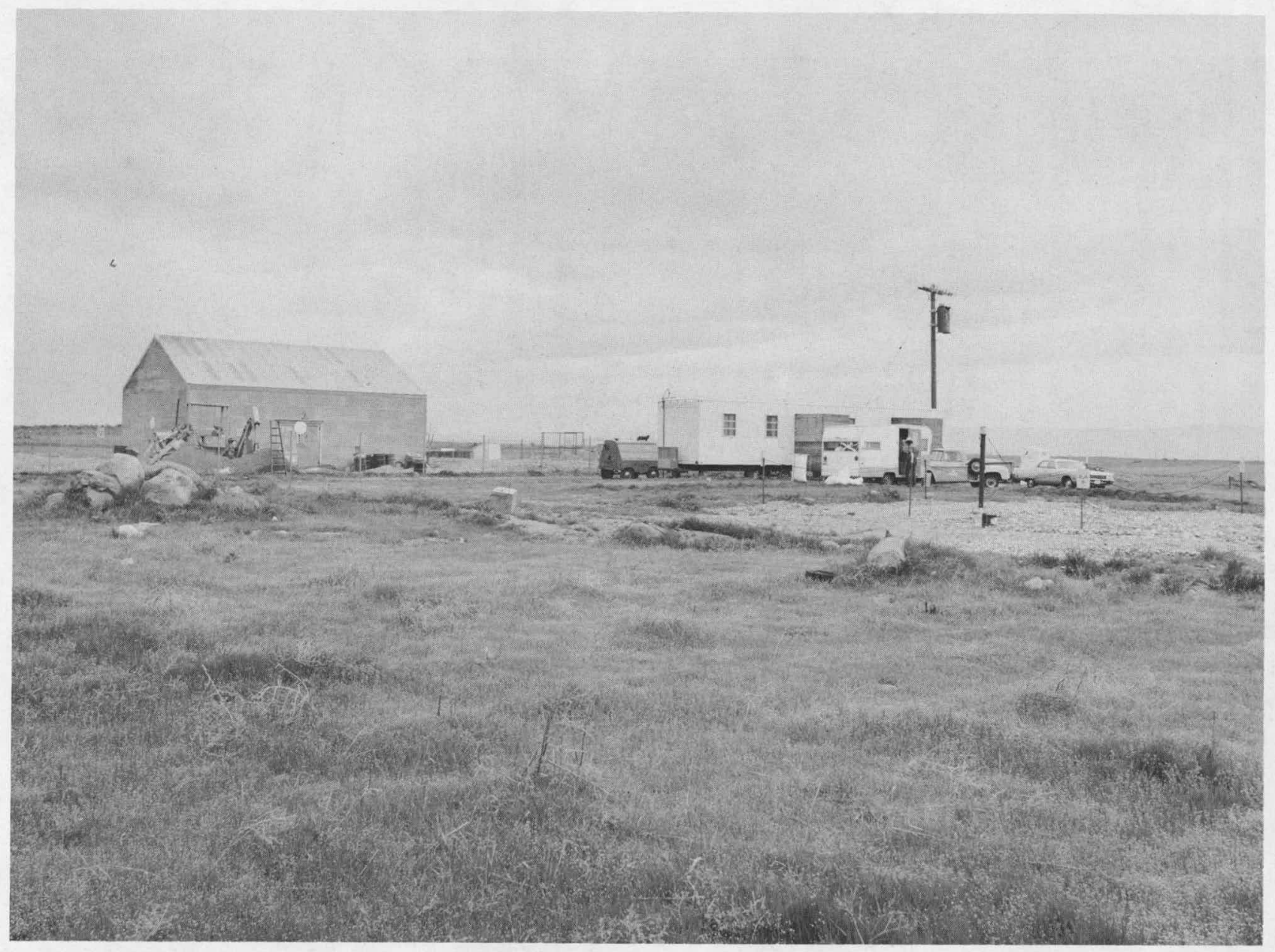

FIGURE 2

P-11 SITE PRIOR TO DEMOLITION

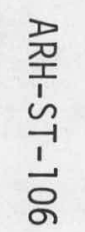


Company, Battelle Northwest, and United Nuclear Industries. The P-11 Facility was designated as the number one ARHCO priority for demolition and removal. The study established a cost and schedule for demolition of $\$ 210,000$ in fiscal year 1974, with additional funds up to $\$ 420,000$ for fiscal year 1975. Responsibility for the P-11 Facility demolition was transferred from BNW to ARHCO in August 1973, with the Atomic Energy Commission, Richland Operations office, approving the financial plan for expenditures from the fiscal year 1974 operating (expense) budget to initiate the decommissioning program.

WORK PLANS AND PROCEDURES

With the responsibility of the P-11 Facility cleanup given to ARHCO, the . assignment of personnel and the development of a preliminary work plan was initiated in August 1973. Personnel from ARHCO Design and Development, Radiation Monitoring, and Project Management organizations were selected to integrate and follow the work with Project Management having prime responsibility and authority. A plan was developed which delineated the scope of work to be accomplished and specified special procedures and equipment needed to safely dismantle and remove the 120 Building and adjacent waste crib. In addition to the normal requirements to restore services and provide a field office, it was determined that a high efficiency particulate exhaust (HEPA) system and an entry-exit airlock would have to be installed on to the 120 Building for contamination control.

The preliminary work plan was formalized as a document and issued in December 1973 to guide the onsite cost.plus fixed fee (CPFF) construction service contractor, J. A. Jones Company, in the field work. After lighting services were restored to the facility in March 1974, a resurvey of the facility was made by ARHCO Radiation Monitoring (Figure 3 ). This survey revealed plutonium contamination four to five times higher than indicated in survey made earlier by Battelle Northwest. Plutonium contamination up to $1,000,000$ disintegrations per minute, and smearable contamination up to $300,000 \mathrm{~d} / \mathrm{m}$ was found in the mix room. The original survey was hampered by lack of adequate lighting and was not as extensive. The survey prompted a reappraisal of the work plan and the establishment of a hazards review team for the purpose of evaluating all aspects of planned work, including plans and procedures, and to make recommendations for the safe conduct of the P-11 cleanup program.

Based on initial recommendations of the hazards review team, a work procedure was prepared in February 1974 to supplement the basic work plan which provided more details and specific guidelines to be used for the safe conduct of the planned work. A safety and environmental polution analysis of the planned P-11 Facility cleanup program was made concurrently in accordance with Atomic Energy Commission requirements. The work plan and environmental analyses documents were approved by the $A E C$, 


\section{P-II SURVEY}

Direct $d / m$

to 20,000

5,000

10,000

5,000

500

5,000

10,000

$2 " \times 4$ "s bolted to wall (upper)

$2^{\prime \prime} \times 4$ "s bolted to wall (lower)

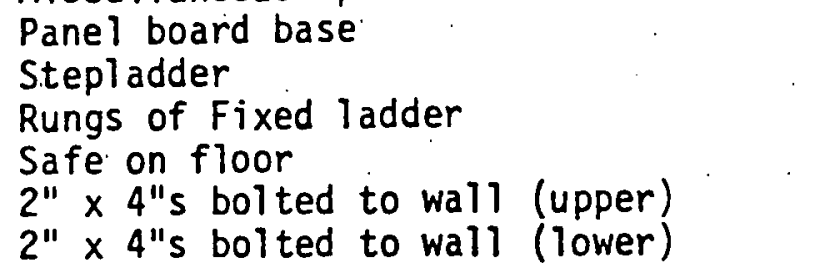

Cell $\# 2$

Horizontal Surfaces

2,000

Smears d/m

\section{Cel1 \#}

Lab

Wall under mix room window

Horizontal surfaces (general)

to

50,000

5,000

5,000

5,000

1,000

2,000

2,000

$<500$

1,000

$<500$

Mix Room

Small duct over concrete fill

Pipe braces on wall

Walls above concrete fill

100,000

20,000

$1,000,000$

$1 \%, 000$

Change Room

Top of shower

Sinks, water tank and miscellaneous surfaces

5,000

2,000

1,000

1,000

\section{East Corridor}

Miscellaneous material in plywood box Work benches, Power tools, Floors and adjacent walis

to

to

5,000

No smears

2,000

to

1,000

Attic

Vent duct over mix room

Miscellaneous horizontal surfaces to

20,000

1,000

5,000

500

All readings were corrected using factor $\times 10$

Personnel Survey at completion of work

$\begin{array}{lr}\text { Coveralls } & <500 \mathrm{~d} / \mathrm{m} \\ \text { Shoe covers } & <500 \mathrm{~d} / \mathrm{m} \\ \text { Gloves } & \text { to } \quad 500 \mathrm{~d} / \mathrm{m}\end{array}$

Spot check with G.M. Inst. (all rooms) $<200 \mathrm{c} / \mathrm{m}$ 
and the authorization to proceed with physical demolition was obtained on April 16, 1.974. Work on the site preparation and installation of the auxiliary equipment had progressed to near completion by this time. A stepwise demolition and removal schedule was prepared by Project Management which would detail day-to-day work planned, but would have the needed flexibility for changes required in the operation as reviewed weekly by. ARHCO Project Management, ARHCO Radiation Monitoring, and J. A. Jones Company.

At this time it was necessary to update the work plan to reflect planned changes in demolition sequence, airlock size and arrangement, and direction of airflow. The revised work plan document would include details of the stepwise schedule, new survey information, and permit use of fiberglass reinforced polyester (FRP) plywood boxes for transuranic burial along with the standard approved steel containers. The inclusion of the FRP container was made in light of the use of the container at other Atomic Energy Commission sites, and a significantly lower cost compared to approved steel containers. In conjunction with this, the application of current Atomic Energy Commission policy guidelines for classifying transuranic waste permitted most of the P-11 Facility to be buried in the mixedfission product trench, thus eliminating expensive burial containers required for 20 -year retrievability.

\section{ORGANIZATION}

An organizational chart was prepared and approved by ARHCO and J. A. Jones Company management for the conduct of the work. The chart delineated prime authority and chain of command in the event of an emergency. Atlantic Richfield Hanford Company Project Management was given prime authority with integrated responsibilities assigned to $\mathrm{J}$. A. Jones Company and ARHCO Radiation Monitoring. Field work wás closely controlled by the radiation monitor to prevent the spread of contamination to personnel and the environs. In addition, the radiation monitor maintained a detailed record of all activities and radiation surveys, obtained samples, and interpreted work $\mathrm{plans}$ and procedure as dictated by what problems or conditions were encountered as demolition work progressed.

A plan for fire protection was also prepared in view of the remote location of the P-11 Facility from adequate protection services. Both radio and telephone communications were established in the event of an emergency. The organizational chart and fire plan are included in the Appendix section as Attachments $B$ and $C$, respectively.

\section{AUXILIARY EQUIPMENT DESCRIPTION}

Prior to starting demolition of the 120 Building, a number of support facilities were required to be procured or fabricated, tested and installed. The principal auxiliaries were the (1) airlock, (2) ventilation-filtration system, (3) radiation monitoring system, and (4) utilities which included water, power, and telephone services. In conjunction with these items a 60-foot mobile trailer for office and lunchroom, a 12-foot trailer for special work procedure (SWP) clothing, and a chemical toilet were obtained on a rental basis and located at the site. 


\section{AIRLOCK STRUCTURE}

The airlock was critical to effective contamination control and subjected to a thorough review as to utility and practicality. The original airlock conceived and specified in the work plan was large enough to accomodate the transport truck and loading equipment. A review of this arrangement presented the problem of having to survey and release the truck each time a load was transported to the burial grounds. Also, difficulty in handling large, heavy burial boxes inside the airlock using a fork lift truck was apparent. The structure finally agreed on and constructed was a modified design with partitions to include (1) an airlock where filled waste containers and work personnel could be. surveyed, (2) an SWP change room, (3) a radiation equipment monitoring room with phone and desk, and (4) a special material storage room. The structure was plywood and frame construction and installed on a non-reinforced concrete floor to simplify demolition when cleanup work was completed. Electricity, water, telephone, and evaporative type air cooler service were provided to the facility. The structure was located adjacent to the 120 Building with a four-foot connecting transition section between the two building (Figure 4). The structure was located on the east side of the 120 Building since this was the cleaner area, by contamination standards, and free of rubble from the fire. A plot-plan sketch of the airlock structure is shown in the Appendix section as Attachment D.

\section{VENTILATION-FILTRATION UNIT}

The ventilation-filtration unit was comprised of a nine-bank HEPA filter housing. with corresponding prefilters, a seven and one-half horsepower blower, and a square-to-round sheet metal transition duct leading from filter housing to the 120 Building (Figure 5). The inlet duct was equipped with a grille and fiberglass cloth to retain large dust particulates prior to. reaching the main filters, which was instrumental in not having to change the prefilters or HEPA filters during the course of the demolition work. Frequent replacement of the fiberglass cloth was necessary because of the dusty conditions and drop in room negative pressure during demolition. The assembly was located on the west side of the 120 Building so that the airflow would be directed from the area of relatively low contamination to the higher contamination area and then through the filters to the atmosphere. A RADéCO* constant air alpha air monitor was installed downstream of the filter bank and provided continuous monitoring of the stack exhaust with alarm annunciation and recording inside the radiation monitoring room. A sketch of the ventilation-filtration unit arrangement is shown in the Appendix as Attachment $E$.

A 2,000 cubic feet per minute evaporative cooler was installed to discharge into the SWP change room when temperatures in the 120 Building became too high for workers. The cooled air was directed through the airlock and into the work area, and alleviated the temperature problem.

*Trade name - Radiation Detecting Equipment Company; Inc. 


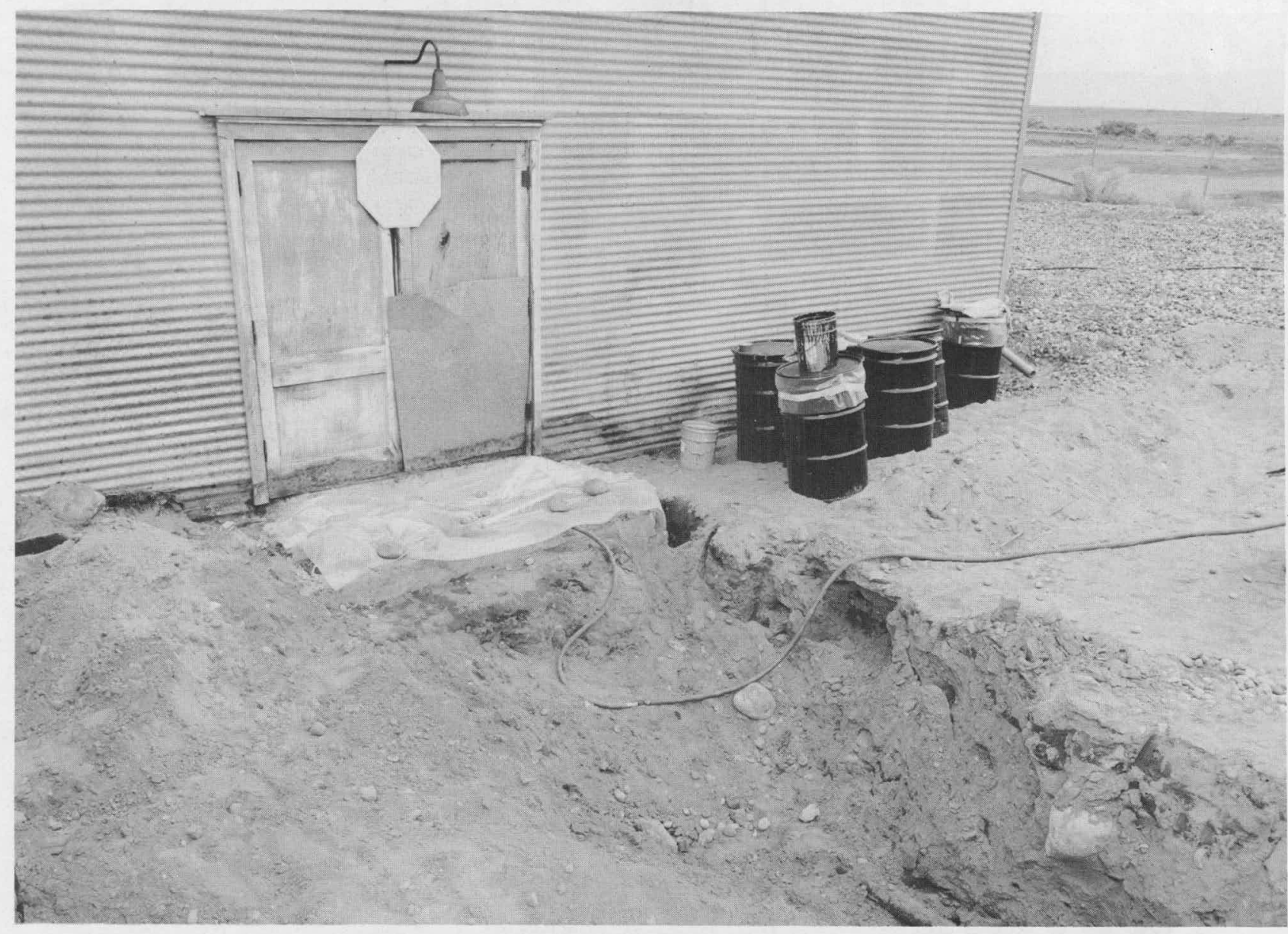

FIGURE 4

AIRLOCK WITH FRP BOX AND 55-GAL. DRUMS IN FOREGROUND 


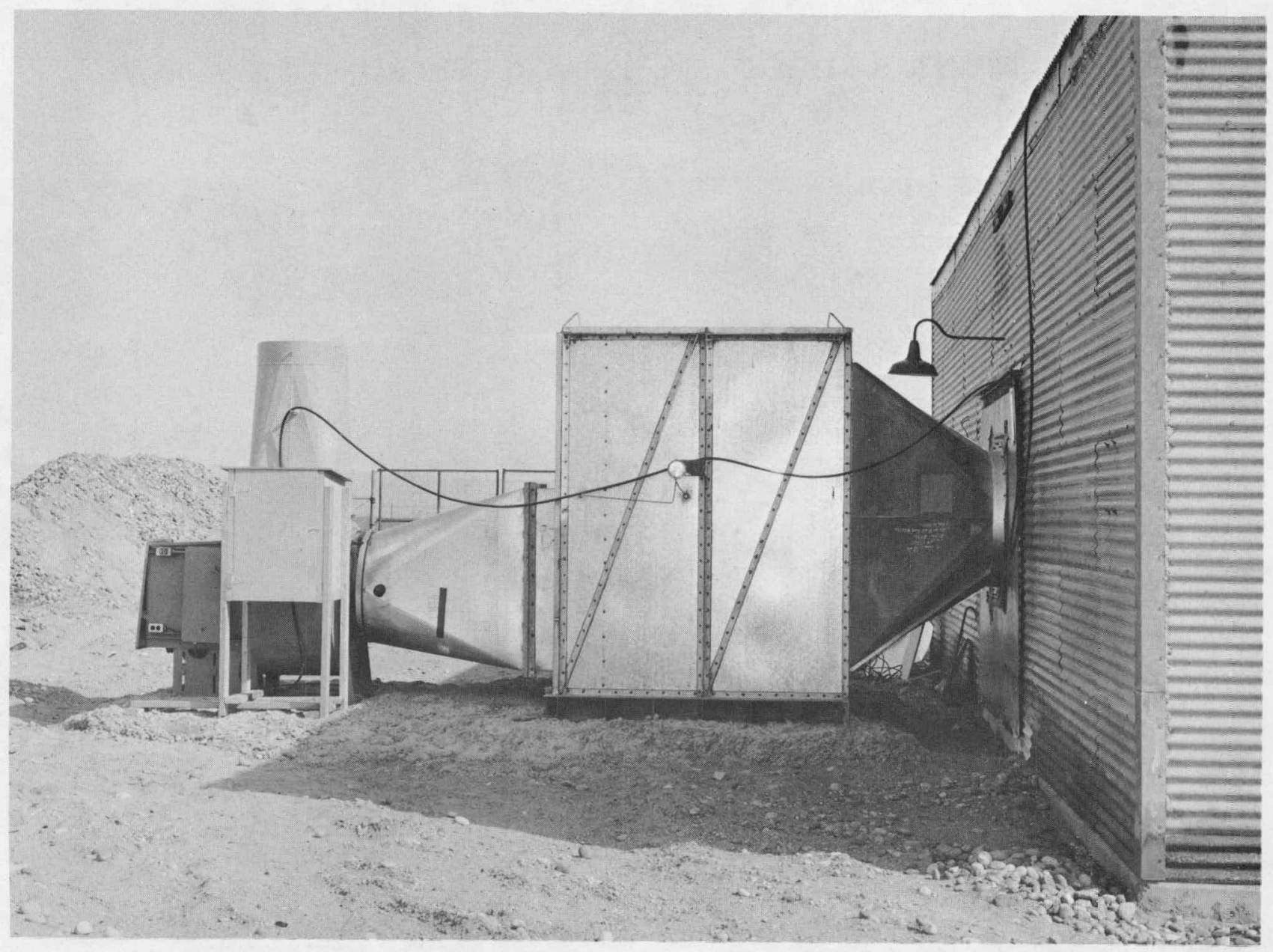

FIGURE 5

120 BUILDING FILTER-EXHAUSTER UNIT 


\section{RADIATION MONITORING SYSTEM}

The potential for release of radioactive nuclides to the environs was of extreme concern. Four RADëCO monitoring units were installed to detect airborne particulates in the 120 Building, airlock, change room, and the previously mentioned exhaust stack. A small vacuum pump was utilized as a central vacuum source for drawing air samples and interconnected with plastic tubing. The units were extremely sensitive and reliable in detection and proved to be an adequate measure for contamination control.

\section{BUILDING SERVICES}

It was necessary to run new power distribution service approximately one-quarter mile from main $13.8 \mathrm{KV}$ line to site. Power poles, transmission lines, and a 37.5 KVA transformer with three-phase 120/208 volt service were installed for lighting, air conditioning, and other utilities. Potable water service was obtained by reactivating an existing eight-inch well installed when the P-11 Facility was constructed. The aquifer was approximately 35 feet below ground level, and tested satisfactorily for drinking purposes. The wel1 was cleaned to 50 feet to assure an adequate water supply. A 12 gallon per minute submersible well pump and 80 gallon receiver tank were procured and installed for water supply. A chlorinator was installed as a precautionary measure and serviced routinely by ARHCO. The water service was extended to the office trailer, the SWP change room, and the evaporative air cooler. This well and a second well uncovered southeast of the crib have been equipped with a locking cover and will be the only original P-1l facilities to be retained. The wells will be monitored on a routine basis by Battelle Northwest to check on any changes in aquifer or the presence of any radionuclides.

Telephone service was extended from an existing line approximately two miles southwest from site. The service was run to the radiation monitoring room and the office trailer.

DEMOLITION AND REMOVAL

Preliminary work prior to actual demolition of the 120 Building was started April 14, 1974, and involved clearing the fenced area around the 120 Building of rock and sand overburden spread around as a precautionary measure when the site was abandoned. Contamination was uncovered, but did not extend beyond the foundation, indicating that the water used in fire fighting did not permeate over a large area as originally speculated. The east door entry pad was uncovered and found contaminated to a level of 10,000 disentegrations per minute. The pad and top one-foot of the footing was removed using a jackhammer. The concrete was covered with wet 
rags to contain dust and chipping fragments. The concrete was surveyed and loaded into 55-gallon steel drums lined with eight mil polyvinyl plastic (Figure 6). Each container was sealed with standard drum lid clamp and weighed using a dynamometer attached to the lifting crane. This would be the standard procedure for handling all material removed and loaded out using the various types of containers which included

(1) fiberglass reinforced polyester (FRP) plywood boxes, (2) steel boxes, (3) standard and coated 55-gallon drums, and (4) standard plywood boxes constructed at the site as needed. The typical containers used and method of handling are shown in Figures 7, 8, 9, and 10 . In preparing the site for the airlock it was deemed advisable to uncover a section of the waste line to the crib that ran directly beneath the airlock location. After exposing the pipe by machine and hand digging, a hole was drilled in the pipe and a sample of the pipe residue taken. The sample indicated contamination up to $30,000 \mathrm{~d} / \mathrm{m}$. No external contamination was detected. The section of pipe was cut in three eight-foot lengths using a portable power hacksaw and cuttings collected in a plastic bag taped under the pipe. Wooden plugs were driven into the open ends of the pipe which were then covered with plastic and sealed with cloth tape. The exposed trench was then backfilled and forms placed for concrete floor. The west side of the building was handled similarly for removal of the contaminated concrete entry pad and installation of ventilation exhauster.

A honeybee hive was found between the east door and plywood used to seal the door when facility was abandoned. The bees and honey were collected and turned over to Battelle Northwest for analysis. There was no evidence of the presence of radioactive nuclides.

A11 of the work within the exclusion fence was under SWP conditions and required double coveralls, canvas boots, rubbers, hood, surgical gloves covered with canvas gloves, and assault mask (Figure 11). A multipurpose dosimeter was worn at all times.

Work outside of the perimeter exclusion fence was conducted concurrently with erection of the airlock structure. All burnable debris, old fence posts, tumbleweeds, and dead trees were removed and placed in the open basement of the old 123 Control Building (Figure 12). The debris was burned under control conditions specified by the fire department. The basement space was then filled with clean demolished concrete pads and other debris removed from outside of the perimeter fence. 01d telephone and power poles, which had been stubbed off above ground level when site was abandoned, were removed and burned.

A11 major leaks in the 120 Building skin were sealed to insure a good differential pressure inside the building. The ventilation filter assembly was checked for leakage by the dioctyl phthalate (DOP) method and tested satisfactorily. The system was sized to provide about three air changes per minute. The large air flow was deemed advisable in view of the anticipated heat buildup inside the building during the summer months when major demolition would take place. It was also necessary to 


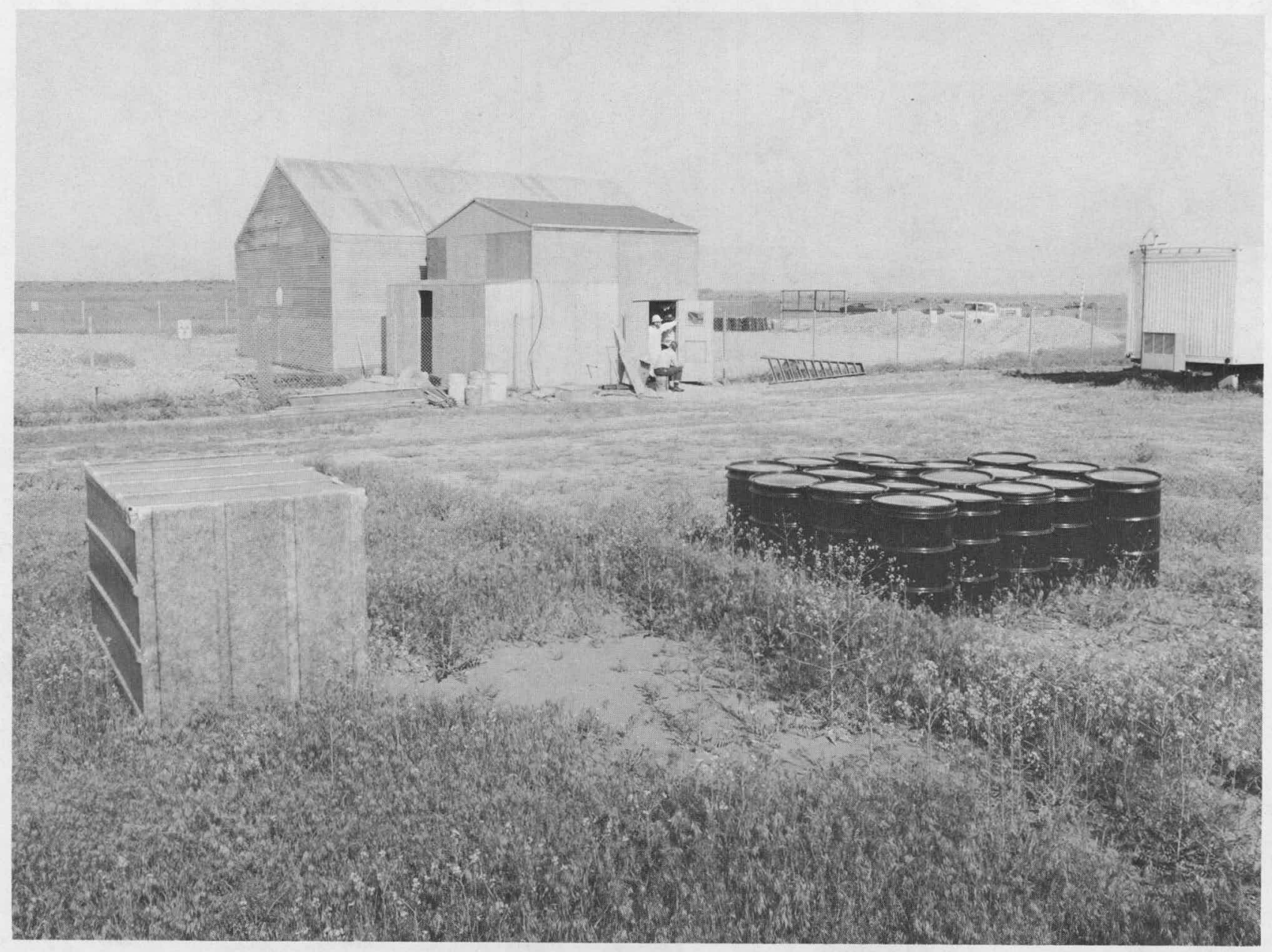

FIGURE 6

EAST DOOR PAD AND DRAIN PIPE UNCOVERED 


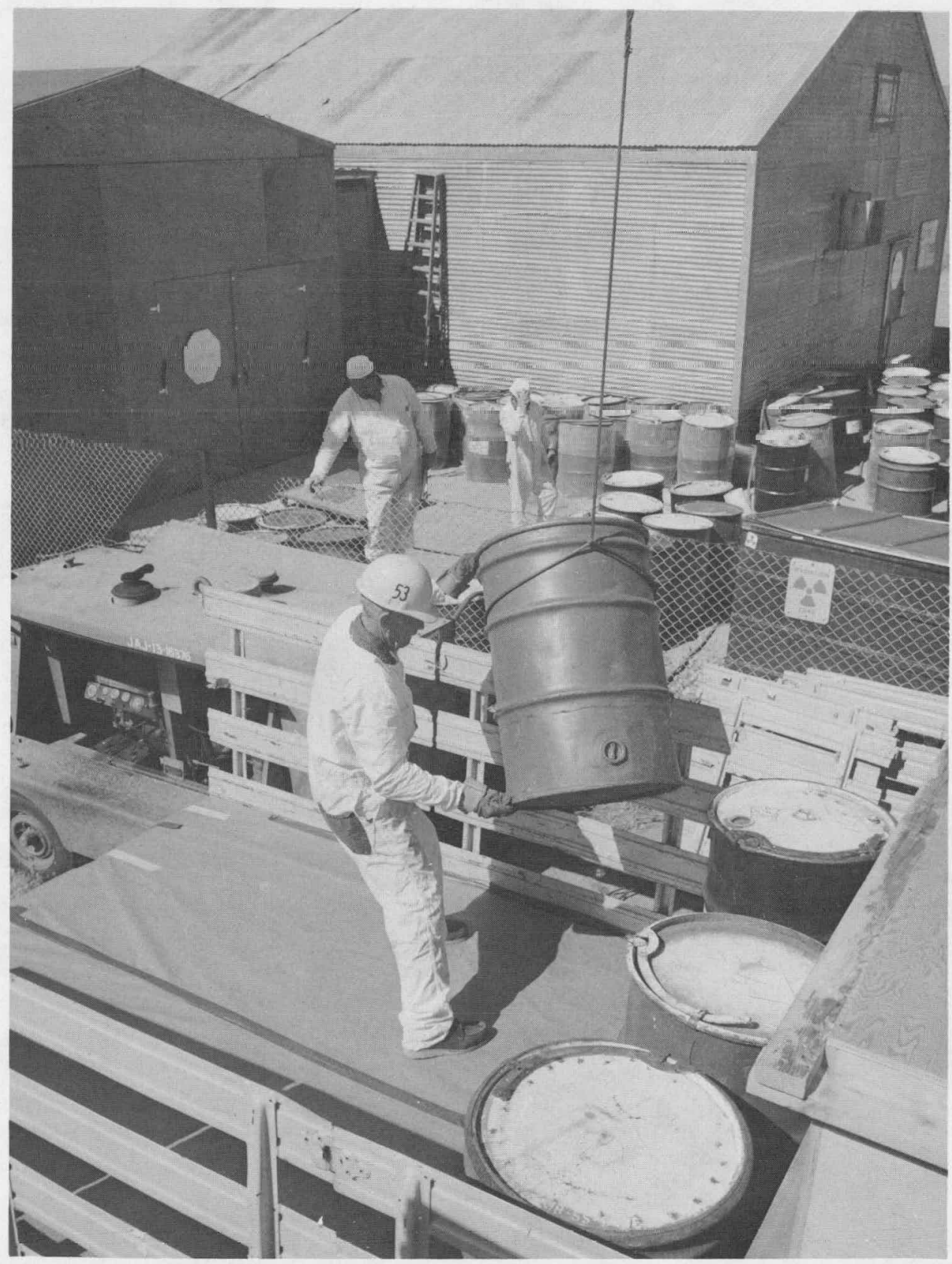

FIGURE 7

CRANE HANDLING FILLED WASTE DRUM 


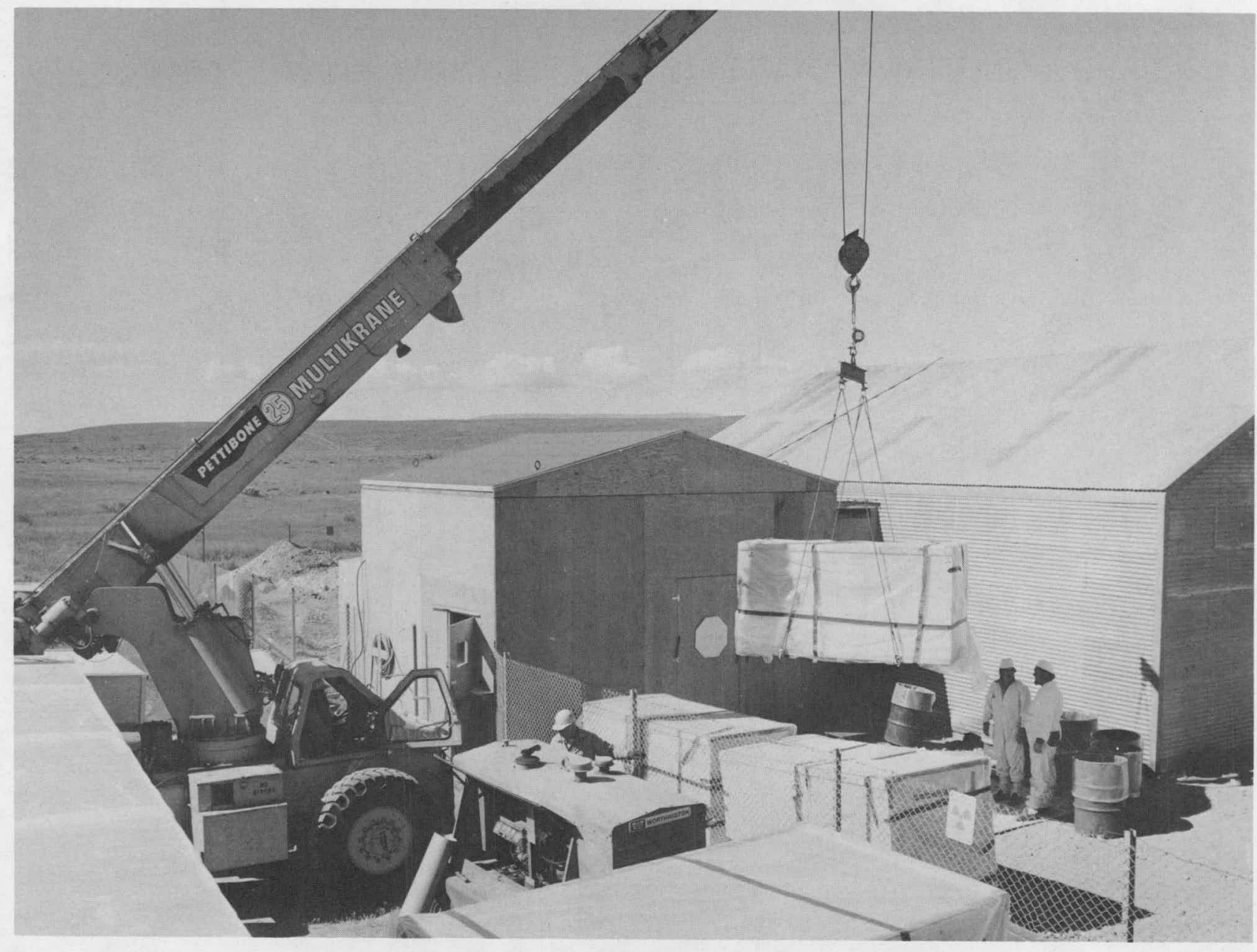

$\vec{ज}$

FIGURE 8

CRANE HANDLING STANDARD PLYWOOD WASTE BOX 


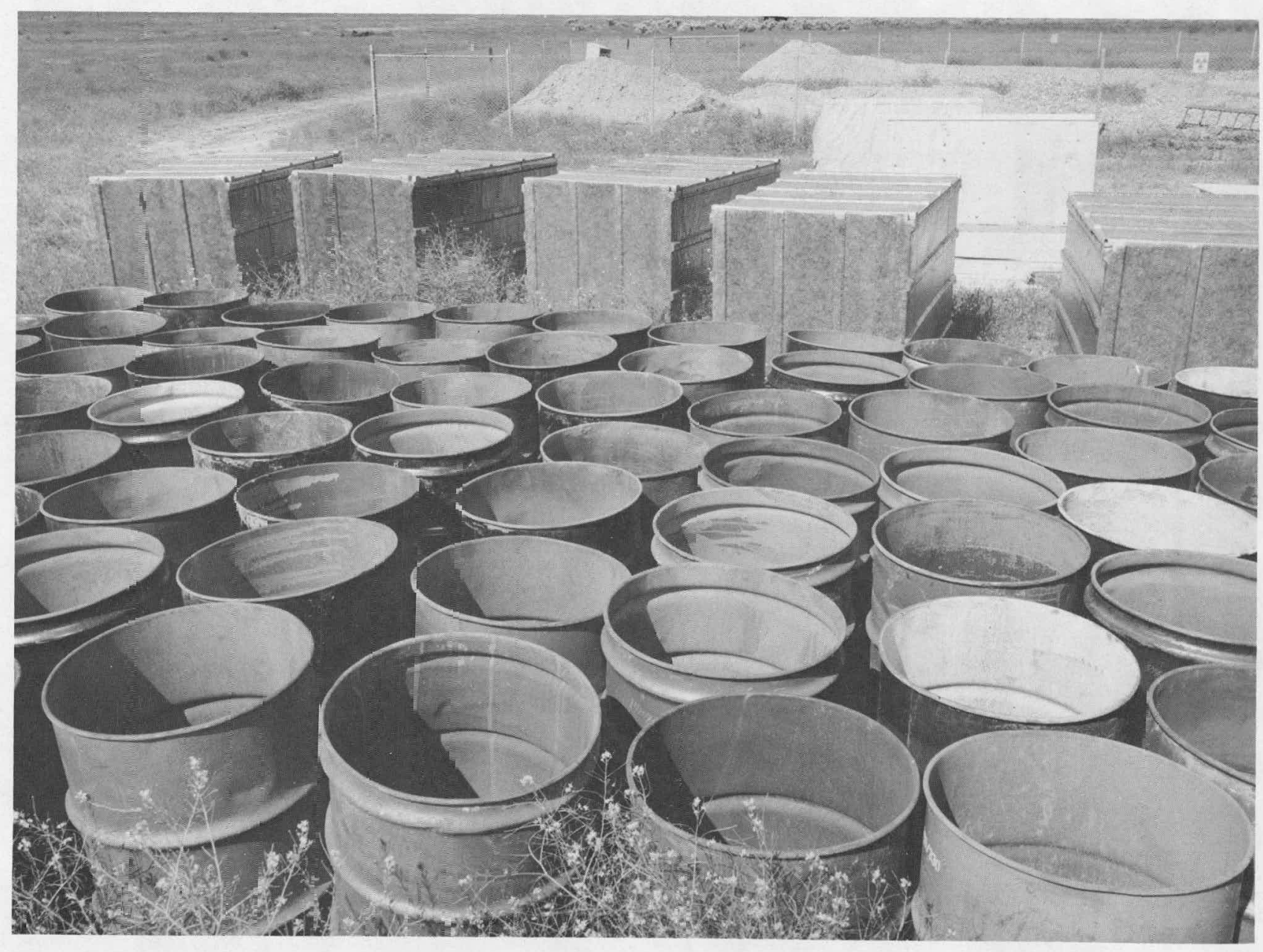

$\vec{\sigma}$

FIGURE 9

TYPICAL WASTE CONTAINERS (STEEL BOXES NOT SHOWN) 


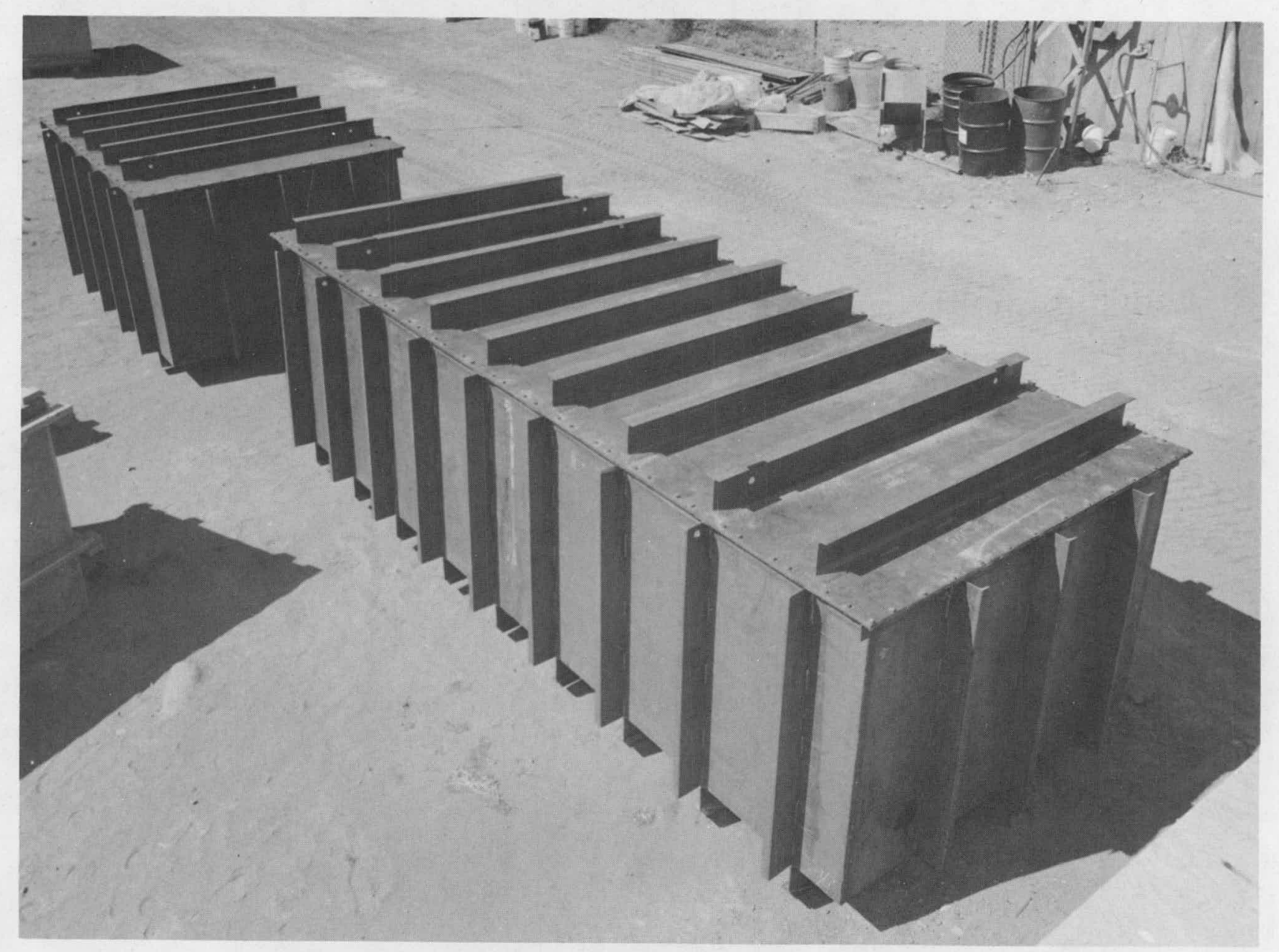

$\vec{\nabla}$

FIGURE 10

STANDARD STEEL WASTE BOX (TRANSURANICS) 


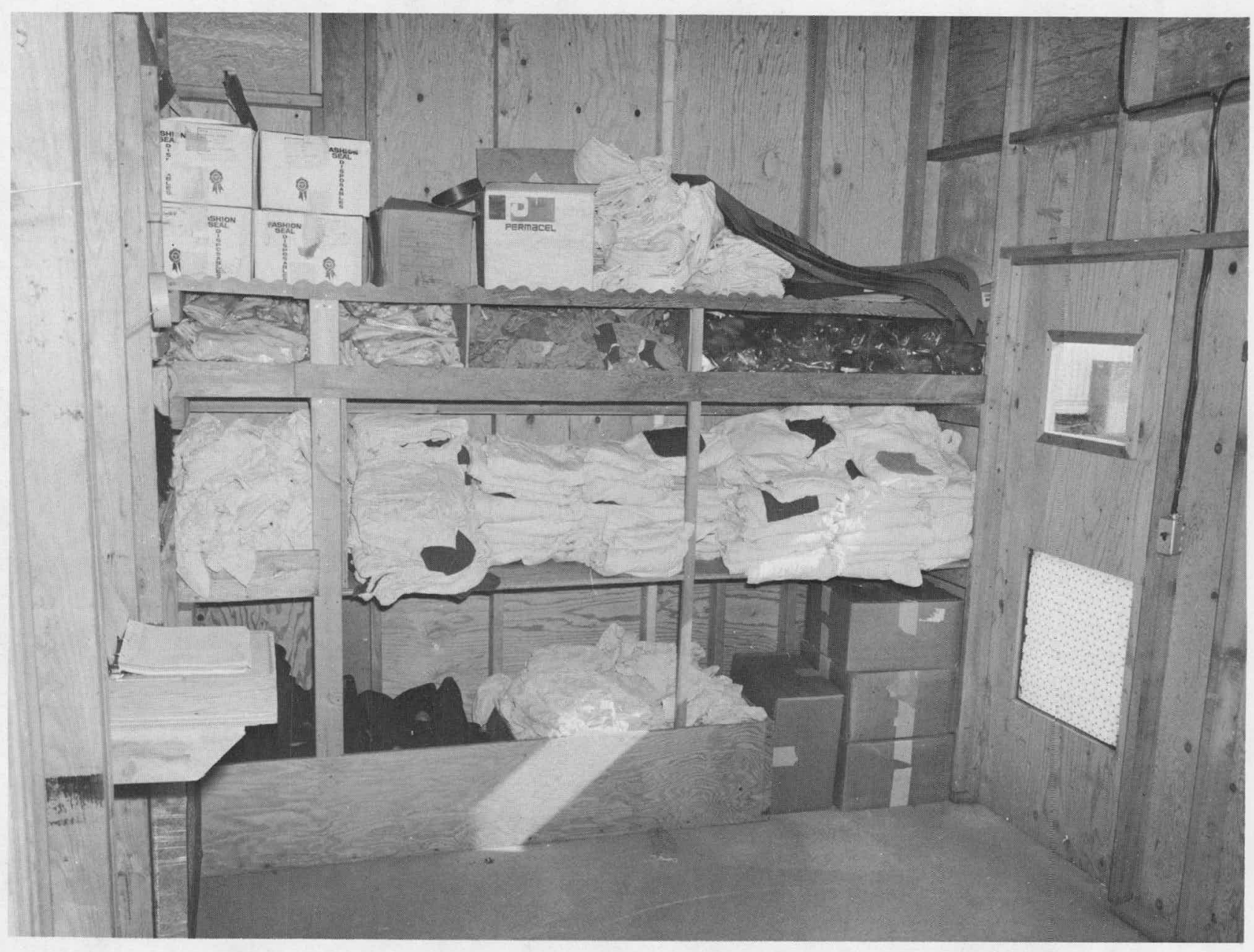

FIGURE 11

CHANGE ROOM SHOWING SWP CLOTHING

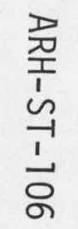




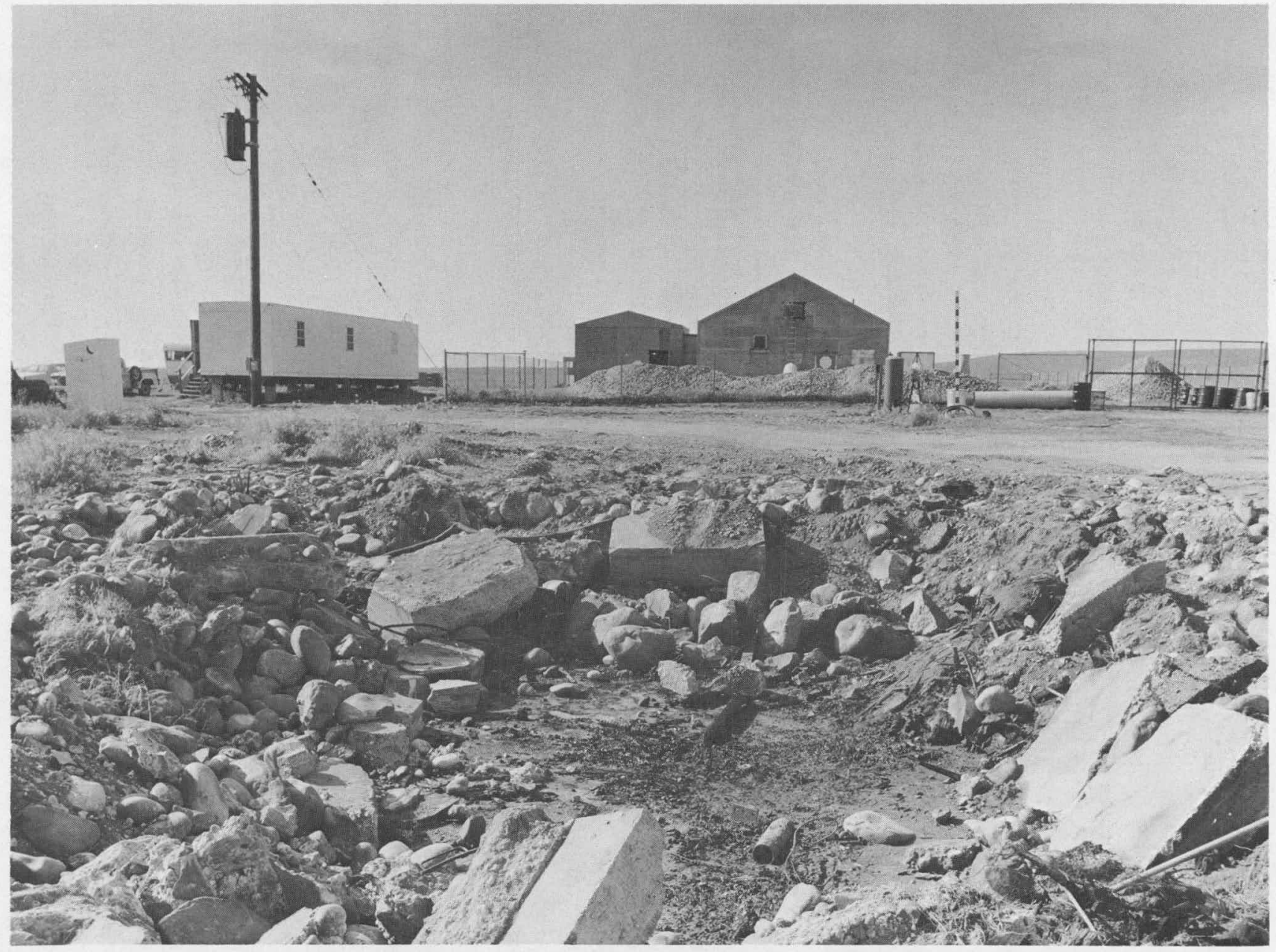

FIGURE 12

OLD 123 BUILDING BASEMENT (WELL PAD IN FOREGROUND) 
fix the smearable contamination inside the 120 Building before actual demolition could be started. This was accomplished by spray painting the interior surfaces with a water soluble latex paint. An airless spray gun was used, and the exhaust system turned off, to minimize the amount of airborne contamination.

With the smearable contamination fixed, removal of all surface-mounted equipment, conduit, lights, controls, and switchgear was initiated. These items were low level in contamination and were loaded into four-foot by four-foot by eight-foot plywood boxes for transport to the 200 West mixedfission burial site. The rock wool insulation used was extremely dusty, but removal and handling was facilitated by the paint sprayed on earlier, which tended to mat the fibers together and contain the dust. This work was followed by the removal of the sheetrock walls and partitions, all of which were found free of contamination on the inside. This opened up the lower level and permitted removal of the highly contaminated ventilation ducts, blowers, and fire-gutted filter assemblies. The reactor test frame and housing were lowered to the floor and dismantled. The contaminated metal components were sealed in transuranic steel boxes for 20-year retrievable storage. The weight and size of this equipment ruled out the use of the smaller FRP boxes for transuranic storage.

The majority of this phase of demolition was performed by laborers, but the removal of any electrical fixtures, piping, sheet metal ducts or steel structures required the use of corresponding craft personnel who were called in as needed.

The demolition of the concrete floor was initiated by removing the two-inch grout overlay, using air-operated chipping guns. Contamination up to $750,000 \mathrm{~g} / \mathrm{m}$ was uncovered in the $\mathrm{mix}$ room area. This necessitated spray painting and papering of the old floor surface as it was uncovered. A number of items were found embedded in the concrete, including tools, pipe, hardware, and plastic tubing.

At this point it was determined that it would be safer and more economical to remove the equipment and grout from the two cells, rather than removing the cells as a single 70 -ton block as originally planned. The grout was soft compared to standard concrete and removal was relatively easy using chipping guns. The main floor and original cell floor were still intact, t'iis providing complete containment within the confines of the building shell for contamination control.

Neutron and gamma counting equipment was used to determine the amount of plutonium in the cells (Figure 13). The readings were inconclusive due to density of concrete, depth of plutonium, and other factors. However, it was ascertained that the total amount of plutonium was small and would not exceed 100 grams. A total of 29 grams was accounted for based on survey and neutron count compared to 15 grams estimated from accountability figures. 


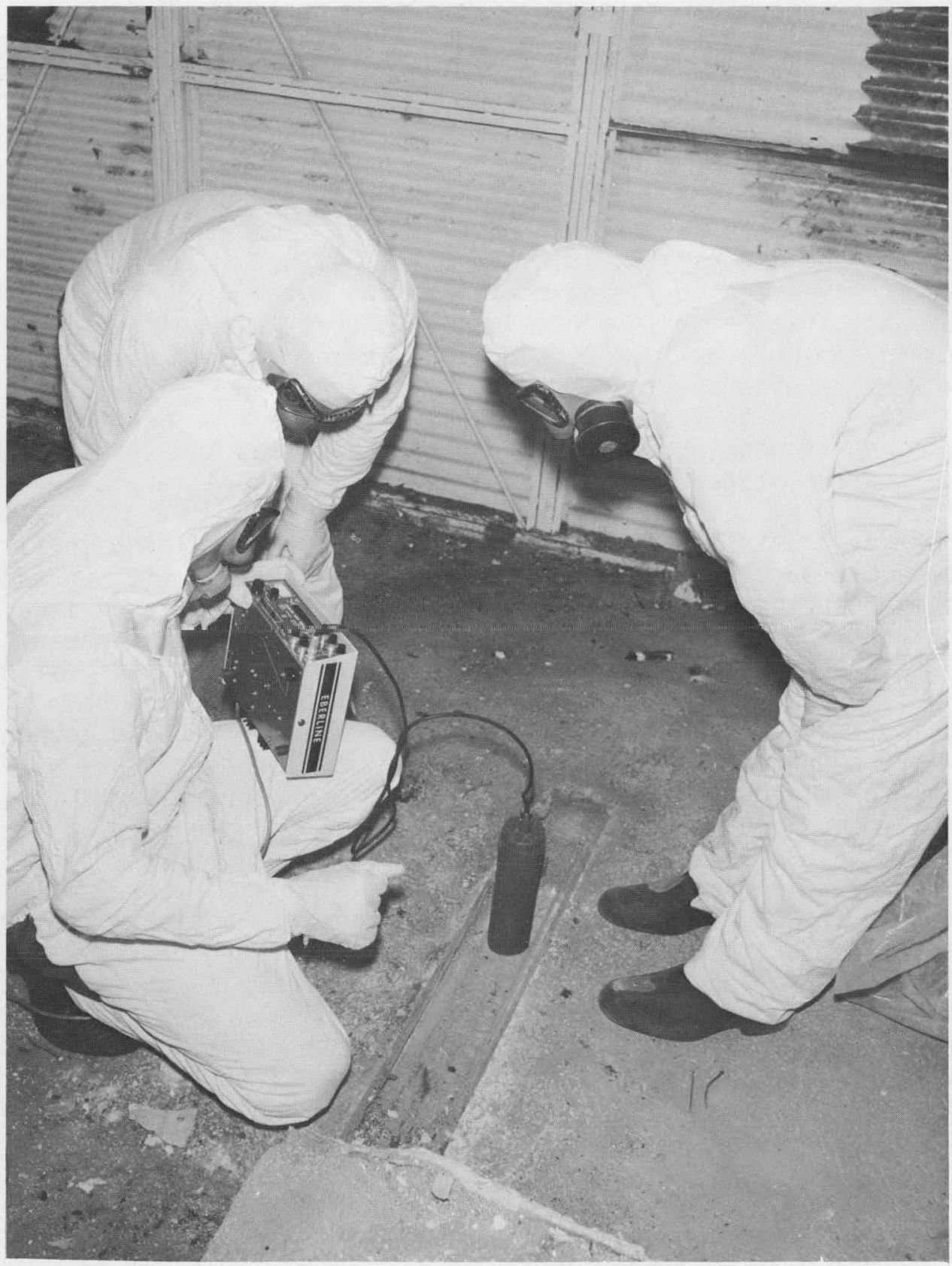

FIGURE 13

NEUTRON COUNTING OF 120 BUILDING CELLS 
Demolition and removal of the cell contents revealed that all criticality testing hardware, reactor vessels, instruments, tanks, grating, piping, wiring, and tools had been buried in the cells (Figures 14 and 15). The steel reactor vessel had been cut into four sections prior to disposal to the cel1. The individual components removed were neutron counted and a more exact plutonium figure ascertained. A1l of the criticality test hardware and equipment was loaded into steel or fiberglassed plywood boxes for 20-year retrievable storage.

Removal of the cell debris revealed contamination on cell floor and walls up to $2,000,000 \mathrm{~d} / \mathrm{m}$. The cells and floor were cleaned to remove loose contamination and then covered with Butvar BR* dispersion, a strippable coating. The coating is a plasticized polyvinyl butyral dispersion in water and is effective in fixing contamination which minimized dusting and airborne contamination while contaminated concrete was being chipped. After the contaminated concrete was removed, the balance of the concrete floor and cell were removed by standard demolition techniques. The cell demolition was complicated by the fact that the cell floor was fourteen inches thicker than the plans showed, and all underground piping was encased in concrete instead of being located directly in the ground (Figure 16).

The ironworker craft strike prevented removal of the building shell on schedule as planned. With other crafts on the job, the crib was uncovered and contaminated soil up to $30,000 \mathrm{~d} / \mathrm{m}$ activity sealed into five-gallon steel containers and combined with other tranuranic waste in one of the steel boxes. The bulk of the contamination was found in the first one-half inch of soil. The surface resembled a dry mud bed and could be removed as a separate layer. The sandy soil below the first layer dropped to about $1,000 \mathrm{~d} / \mathrm{m}$ in count. No detectable contamination could be found after an additional three inches of this soil had been removed. Water sampling of the abandoned well near the crib site has shown no evidence of any radionuclides reaching the water table. The contaminated pipe and concrete sections of the crib were sealed in plastic for nontransuranic burial (Figure 17). The demolition of the 120 Building shell and structure was simplified by removing the roof in one section and dismantling the unit on the ground. This was accomplished by attaching an I-beam spreader with cables on each end to the gabled roof centerline purlin. The complete unit was then lifted with a crane (Figures 18 and 19). The roof structure and steel walls were essentially clean except for spot contamination. The removed and dismantled sections and framework were wrapped in plastic and transferred to the nontransuranic burial site.

The balance of work included removal of the remaining section of drain piping, which had been delayed due to the pipefitter draft strike. The upper one-foot section of the building foundation in the area of the fire was contaminated up to $800,000 \mathrm{~d} / \mathrm{m}$ and was removed for transuranic storage. The balance of the foundation was removed to approximately one foot below grade. The temporary structures and auxiliaries were removed for salvage or re-use. The ventilation filter housing was found contaminated internally up to $20,000 \mathrm{~d} / \mathrm{m}$ and was buried. The perimeter fence and power line were removed and salvaged for use on other active projects.

A standard survey marker showing coordinates, elevation and historical data was located at the approximate center of the 120 Building site (Figure 20).

*Trade name, Monsanto Chemical Company. 


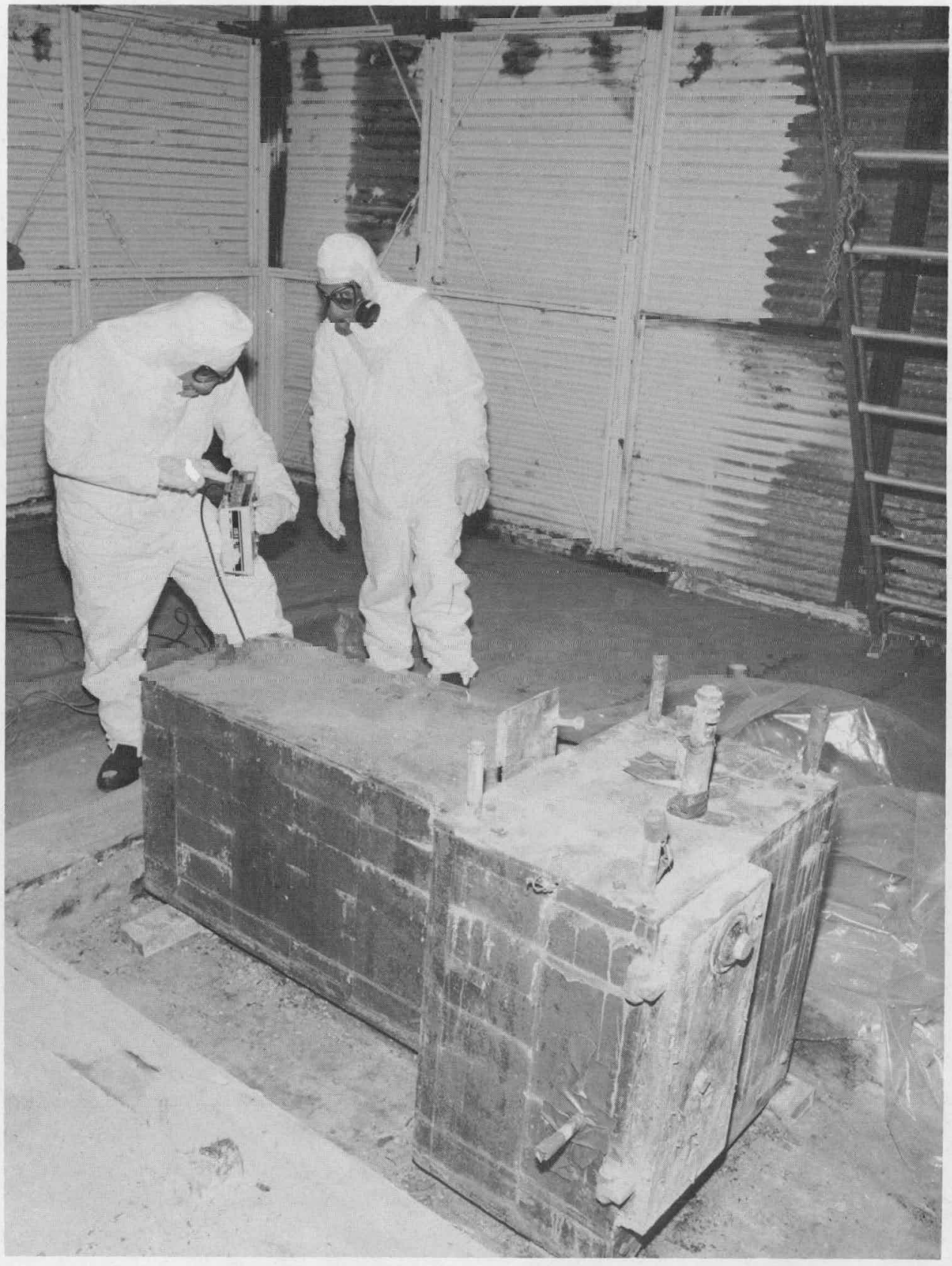

FIGURE 14

MIX TANK VAULT UNCOVERED FROM CELL 


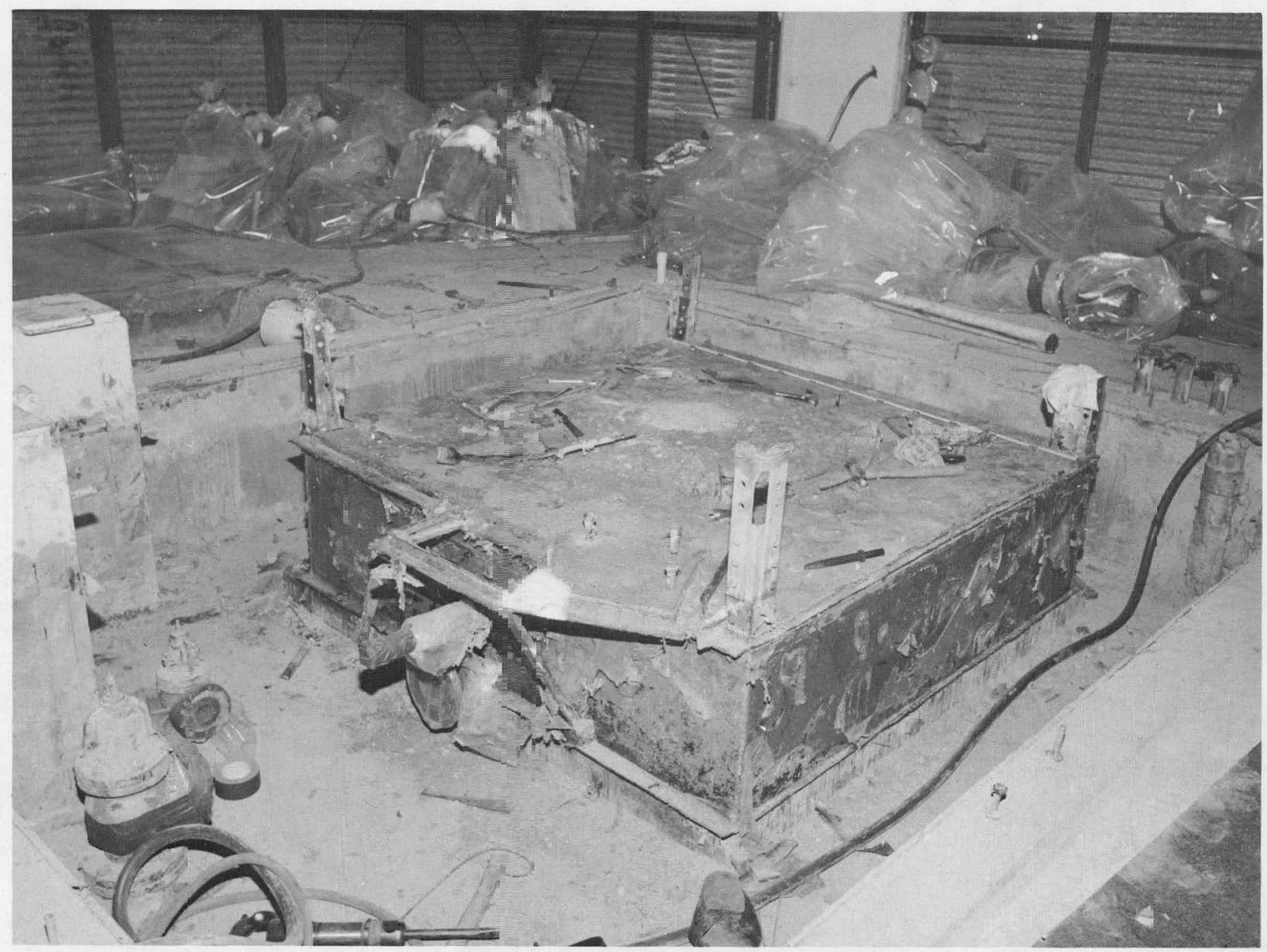

FIGURE 15

REACTION $V=S S E L$ BASE UNCOVERED FROM CELL 


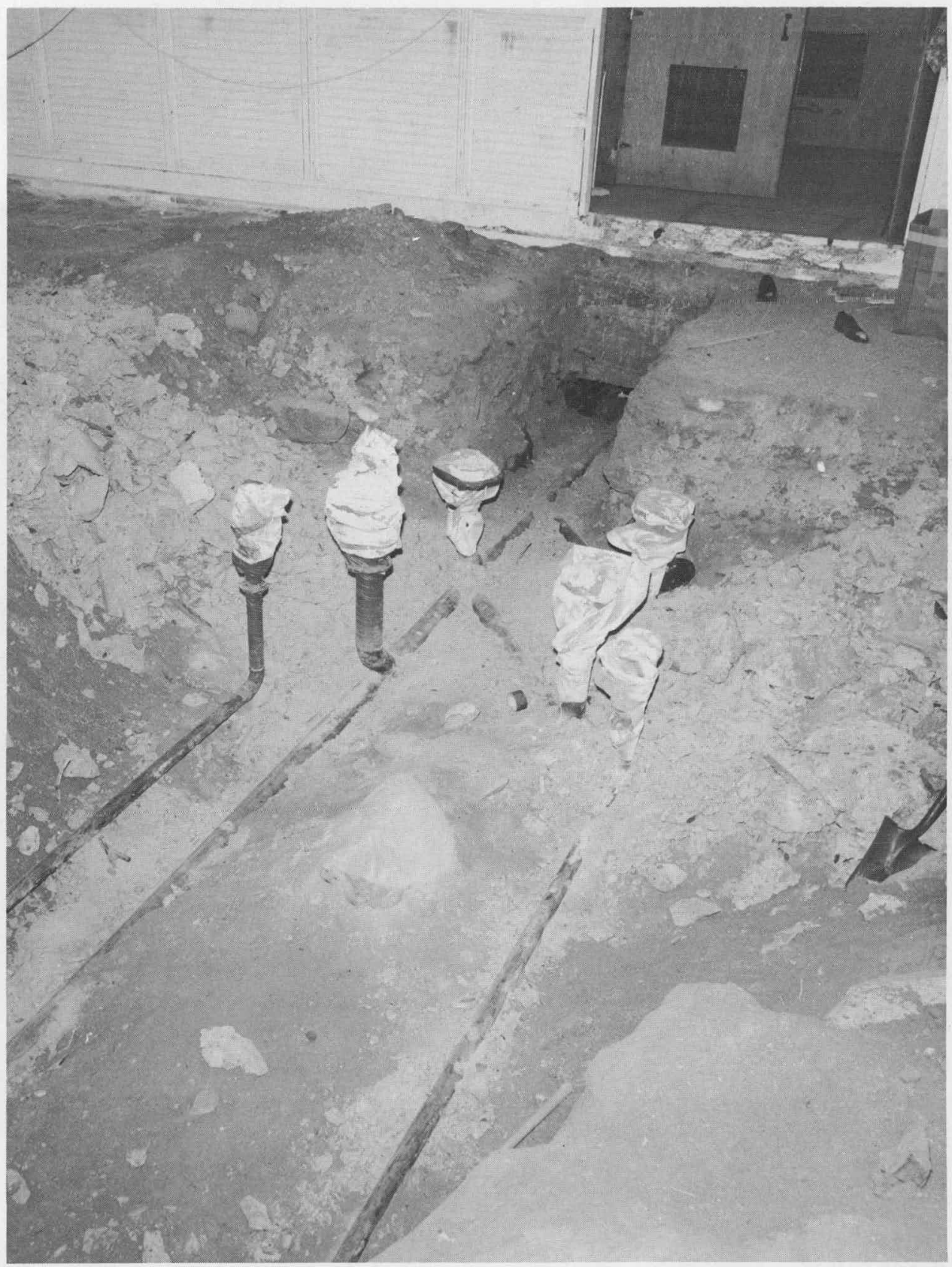

FIGURE 16

UNCOVERED UNDERGROUND PIPING (ENCASED IN CONCRETE) 


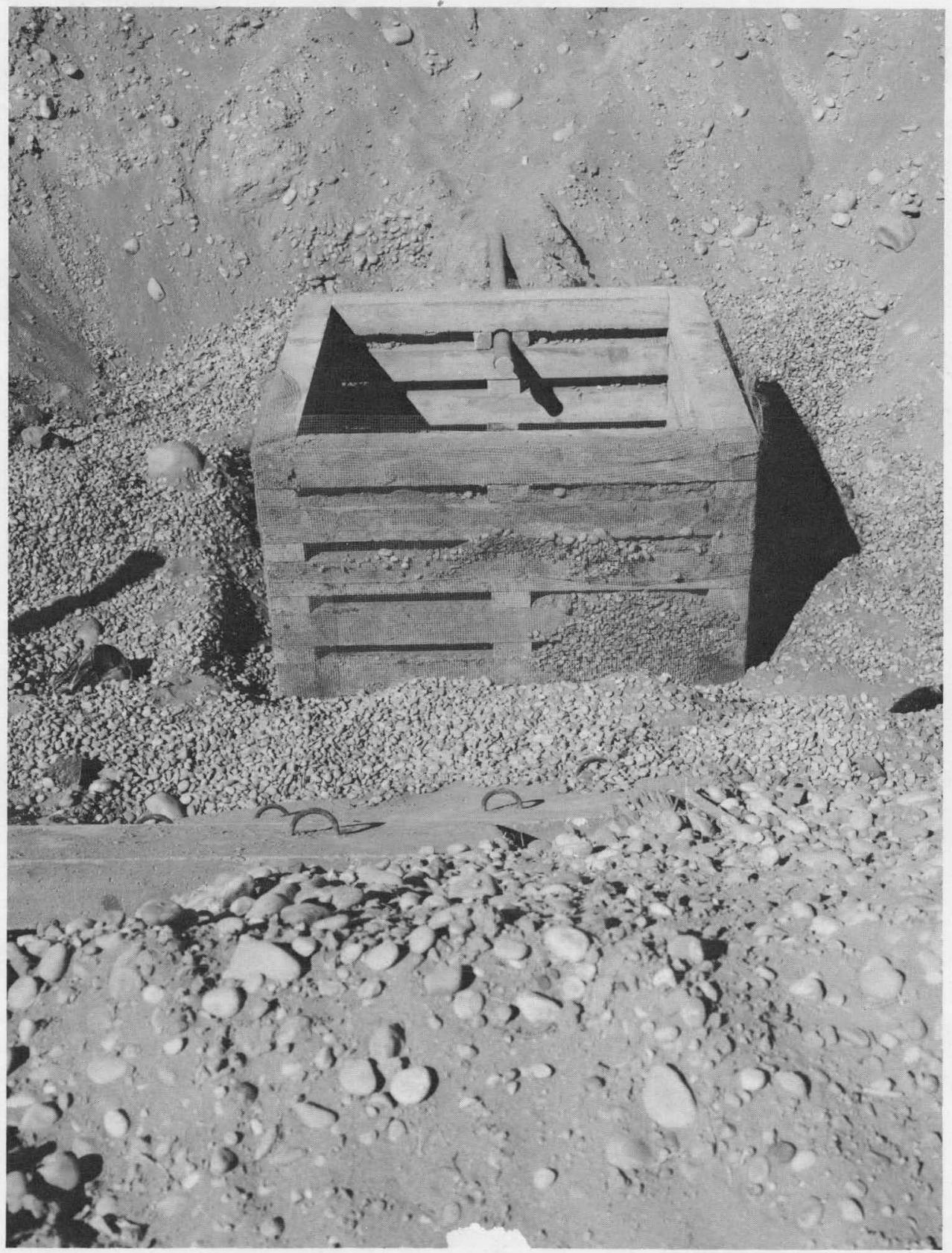

FIGURE 17

LIQUID WASTE CRIB UNCOVERED 


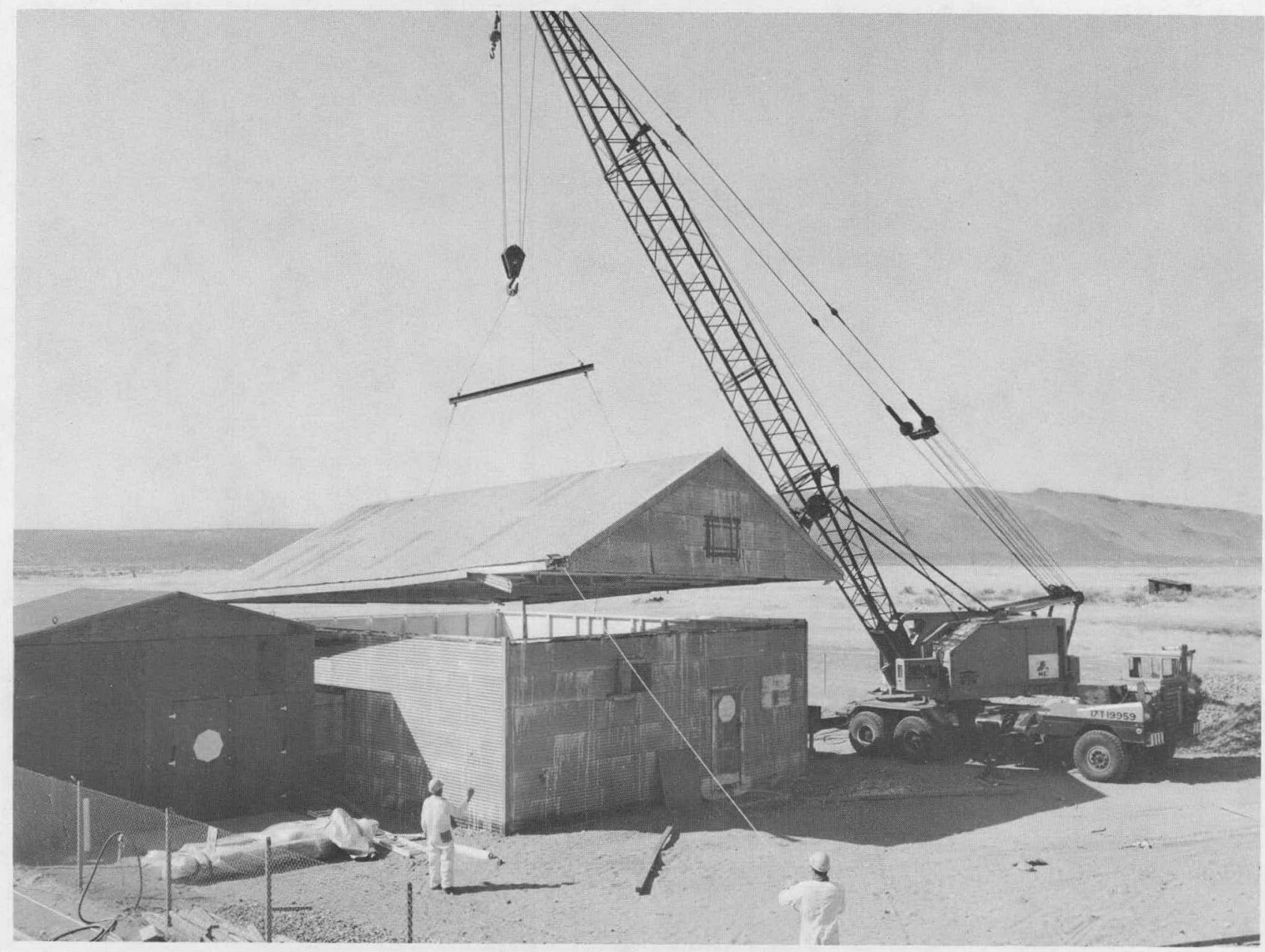

FIGURE 18

CRANE REMOVING 120 BUILDING ROOF IN ONE PIECE 


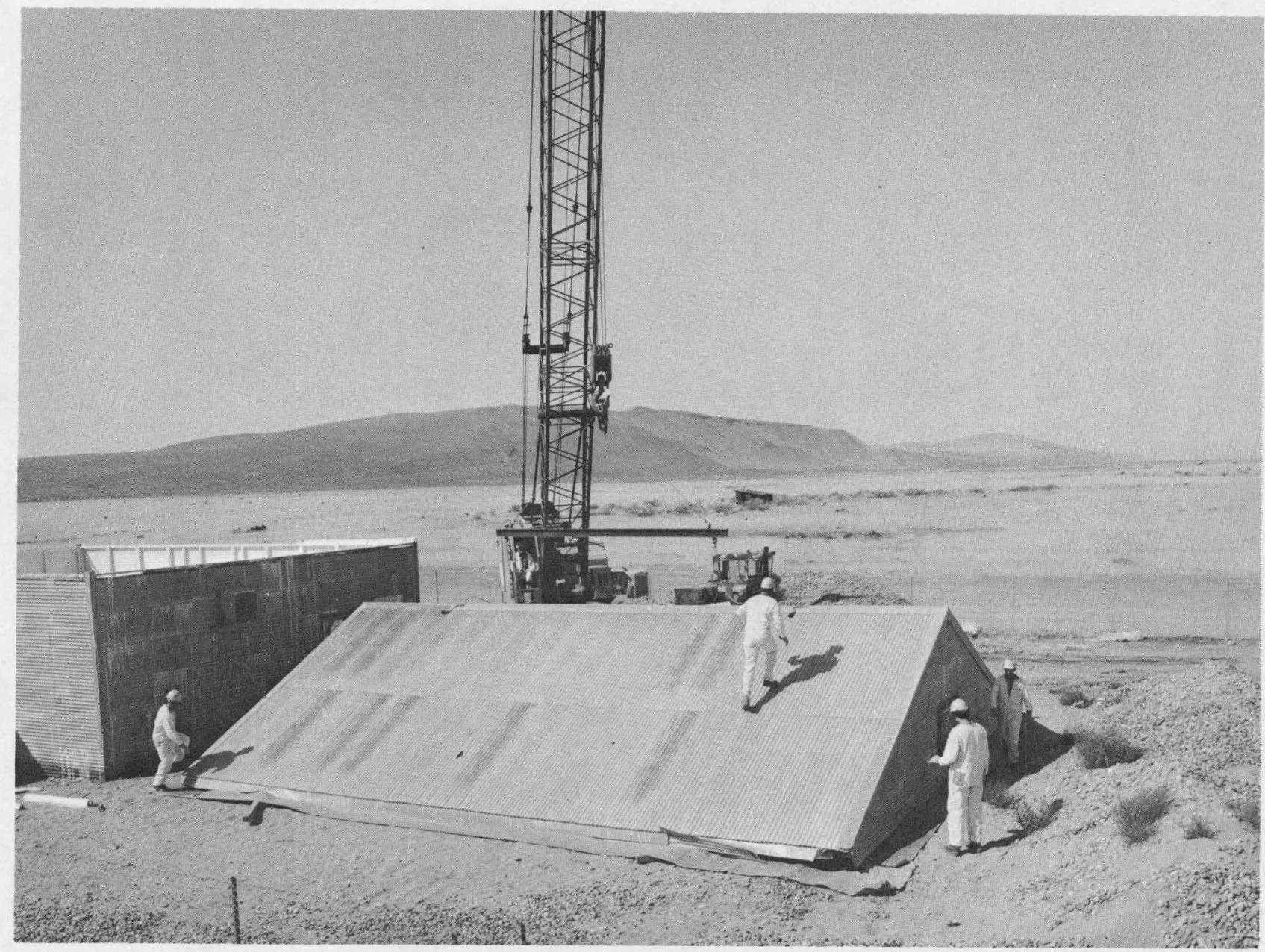

FIGURE 19

120 BUILDING ROOF ON GROUND FOR DISMANTLING 


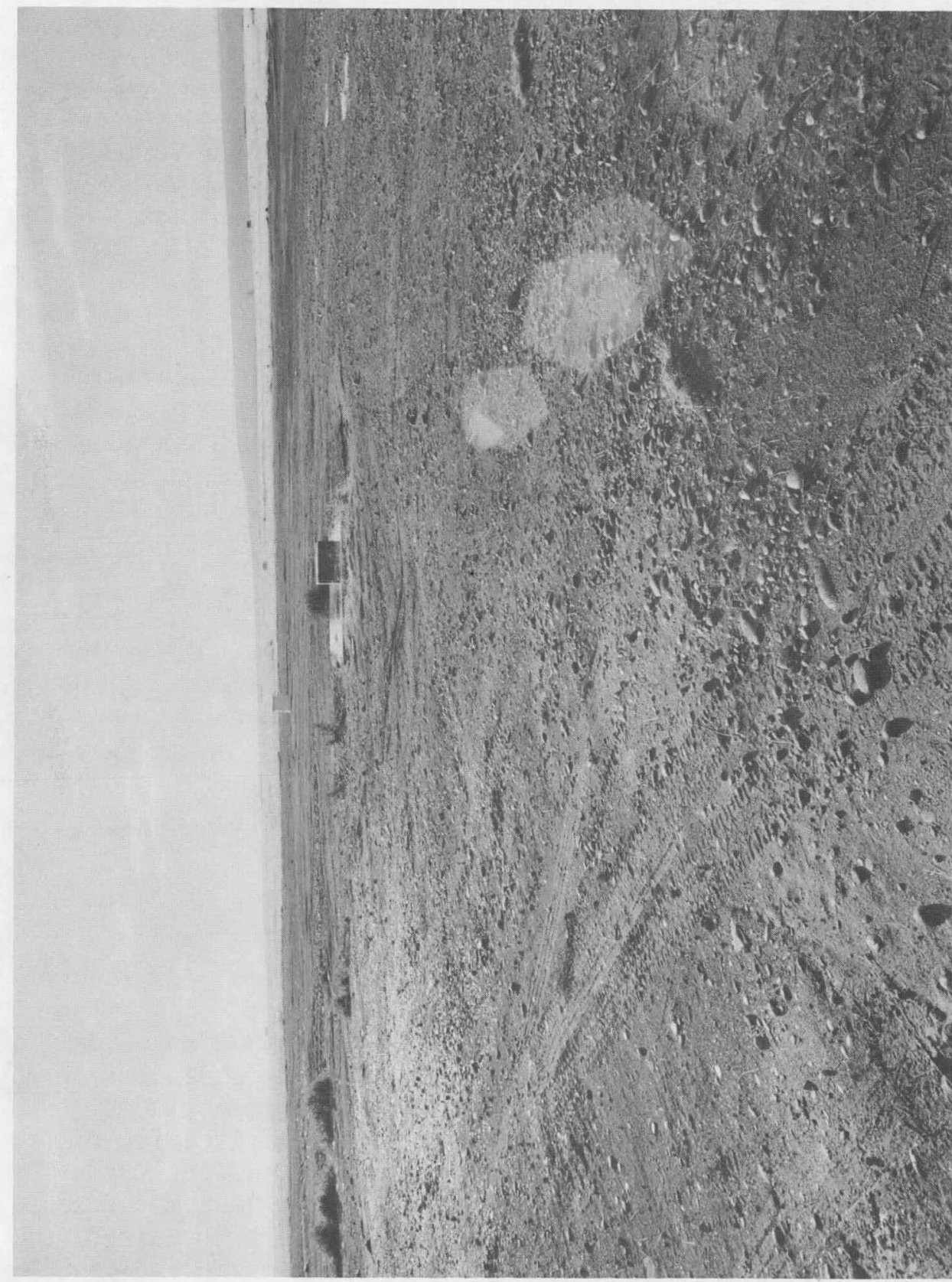

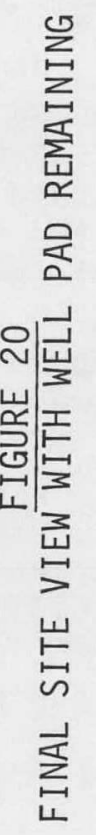


A check of the multipurpose dosimeters worn by the construction personnel and the radiation monitor for the five-month period between Apri1 1, 1974 and September 1, 1974, showed insignificant exposure from penetrating radiation of less than one millinem per day on the average.

The dismantling of the P-11 Facility involved a considerable volume and weight of debris that was transported to the 200 West Area burial site. The seven transuranic waste boxes, fiberglassed plywood and steel, were buried in trench number 8 of the $3 A$ burial garden. All non-transuranic waste was buried in mixed-fission product trenches numbers 12 and 14 in the same burial garden. The seventeen drums of transuranic waste were buried in trench number 7 of the $4 B$ burial garden which is equipped with an asphalt pad to facilitate stacking of drums. A summary of the various type containers transferred to the burial gardens, along with individual weights and volumes, is provided in Figure 21 .

\section{SITE RESTORATION AND RELEASE}

Despite continuous monitoring of site and work area for alpha contamination during demolition, an extensive survey and soil sampling program was instituted at the conclusion of cleanup work. Soil samples were taken to a depth estimated at one-foot into undisturbed soil and encompassing the entire exclusion and crib areas. Emphasis was placed on the southwest corner of the 120 Building site where the fire occurred, as depicted in Figure 22. No plutonium counts were obtained from any of the soil samples using a portable alpha (poppy) survey instrument. Moist samples were dried prior to surveying.

In order to ascertain stability of the soil in the event of high winds, the area was seeded with a rapidly germinating mixture of cereal rye grass and Siberian wheat grain. The area was rilled to a three-inch depth for soil stability, resurveyed, and unconditionally released by Radiation Monitoring for unrestricted access as defined by AEC security regulations for the Hanford site.

\section{COST ANALYSIS}

The demolition of the P-1l Facility involved the utilization of various Hanford contractors, servicing organizations, and equipment. Aside from normal hand tools, the major pieces of equipment used along with prime services are itemized in Figure 23 . The cost for the entire demolition program was $\$ 264,826$, as delineated in Figure 24 . The cost includes approximately $\$ 14,000$ expended for the procurement and modification of a scrapped railroad flat car bed. The assembly was to be used for transporting and burial of the two building cells that were to be removed as a single 70-ton block. The modification of the car bed for required strength and size, necessitated design work and an engineering analysis by Vitro Engineering. The decision to remove the buried contents of the cell piecemeal and to demolish the cells, eliminated the need for the car bed. However, it is estimated that the total demolition cost would have been 40 to 50 percent higher had the original plan been followed. Besides the loss of containment and a potential for the spread of contamination, the extra 14-inch thickness of the cell floor and the fact that underground piping was encased in concrete would have complicated, and more likely prevented, the removal of the test cells as a unit. 


\section{P-II FACILITY}

\section{WASTE DISPOSAL SUMMARY}

Type of Container

55 Gallon drum, mixed fission products

55 Gallon drum, transuranic

Fibre Glass reinforced plywood box

Plywood box

Steel box

Truck load

Transuranic burial

Mixed fission products burial
No.

268

17

5

5,200

640

73

2

6

18,400

24,600

1421

404,395

10,000

2100

. .125

7420

656

480
Vol.(ft. $\left.{ }^{3}\right)$ 
P-II FACILITY

120 BUILDING FOUNDATION

AND SITE FINAL SAMPLE AND SURVEY PATTERN

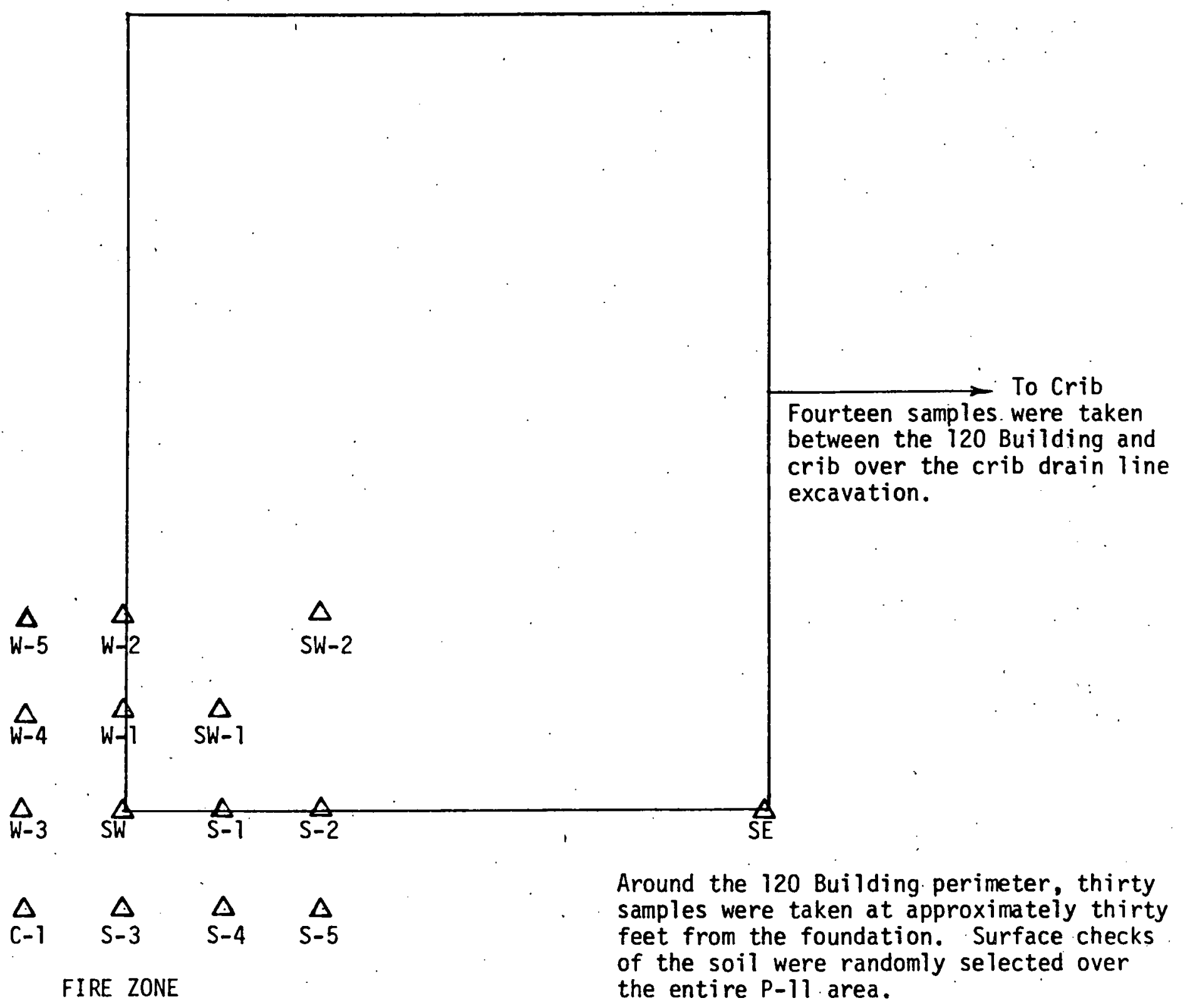




\section{MAJOR. EQUIPMENT USAGE}

ITEM

Pettibone

12-1/2 ton Hydrocrane

Case

750 Crane-Backhoe-Loader

Lorraine

1/2 Yard Backhoe

American

45-ton Crane

Huff

2-1/2 yard Front: End Loader

International

40' Semi-truck

2 ton Flatbed

D-15 Bulldozer

Ingersol 1-Rand

A11 Pavement Breaker

Thor

Chipping Gun

Blu-Brute

Air Compressor

$210 \mathrm{cfm}$ and $250 \mathrm{cfm}$

\section{SERVICE}

Installation of Ventilation-

filtration unit and airlock, also handling of waste containers

Excavation of exterior trenches

Crib excavation

Removal of 120 Building roof:

Removal of gravel overburden around 120 Building

Transport of burial containers

Grading and filling of site

Concrete pads and floor demolition

Stripping of concrete floor and cell surfaces

Air supply to air operated equipment 


\section{P-11. FACILITY CLEANUP COST SUMMARY}

$\begin{array}{lrrrr} & \text { FY } 1974 & \text { FY 1975 } & \text { Total } \\ \text { Vitro Engineering (Design \& Surveys) } & \$ 1,574 & \$ & 616 & \$ 2,190 \\ \text { Battelle Northwest (Photographs) } & 810 & 120 & 930 \\ \text { J. A. Jones Construction Company } & 141,504 & 74,692 & 216,196 \\ \text { Atlantic Richfield Hanford Company } & & & & \\ \text { Radiation Monitoring: } & 6,957 & 8,177 & 15,134 \\ \text { Ventilation Balancing } & 912 & 81 & 993 \\ \text { Project Management } & 21,591 & 4,635 & 26,226 \\ \text { Power Services } & 1,238 & 198 & 1,436 \\ \text { Roadway } & 495 & -0- & 495 \\ \text { Shop Services } & 321 & 90 & 411 \\ \text { Materials \& Equipment } & -0- & 815 & 815 \\ \quad & -175,402 & \$ 89,424 & \$ 264,826\end{array}$

FIGURE 24 


\section{REFERENCES}

1. HW-5645 (unclassified), May 19, 1952, F. E. Kruesi, et al, "Critical Mass Studies of Plutonium Solutions."

2. ARH-2939 REV (unclassified), May. 3, 1973, K. J. Anderson, "Work Plan for P-11 Facility Cleanup."

3. AEC Manual, September 19, 1973, "Standard for Radioactive Protection," Chapter 0524 and Chapter 0511, "Radioactive Waste Management."

\section{ACKNOWLEDGMENT}

The author wishes to acknowledge the assistance obtained from L. D. Bockstanz in the coverage of the P-11 demolition work and in the preparation of this report. In addition, the assistance obtained from the radiation monitor, R. M. Ruitenbeck, in controlling contamination, maintaining historical records, obtaining samples, and providing timely suggestions for improved job performance and safety is appreciated. 
THIS PAGE IS INTENTIONALLY BLANK 
APPENDIX

\section{LIST OF ATTACHMENTS}

\section{Attachment}

A

B

C

D

$E$
Description

120 Building Plot P1an (H-7-692)

P-11 Organization Chart

P-11 Fire Plan

Plot Plan - Airlock Structure.

Plot Plan - Filter-Exhauster Unit 


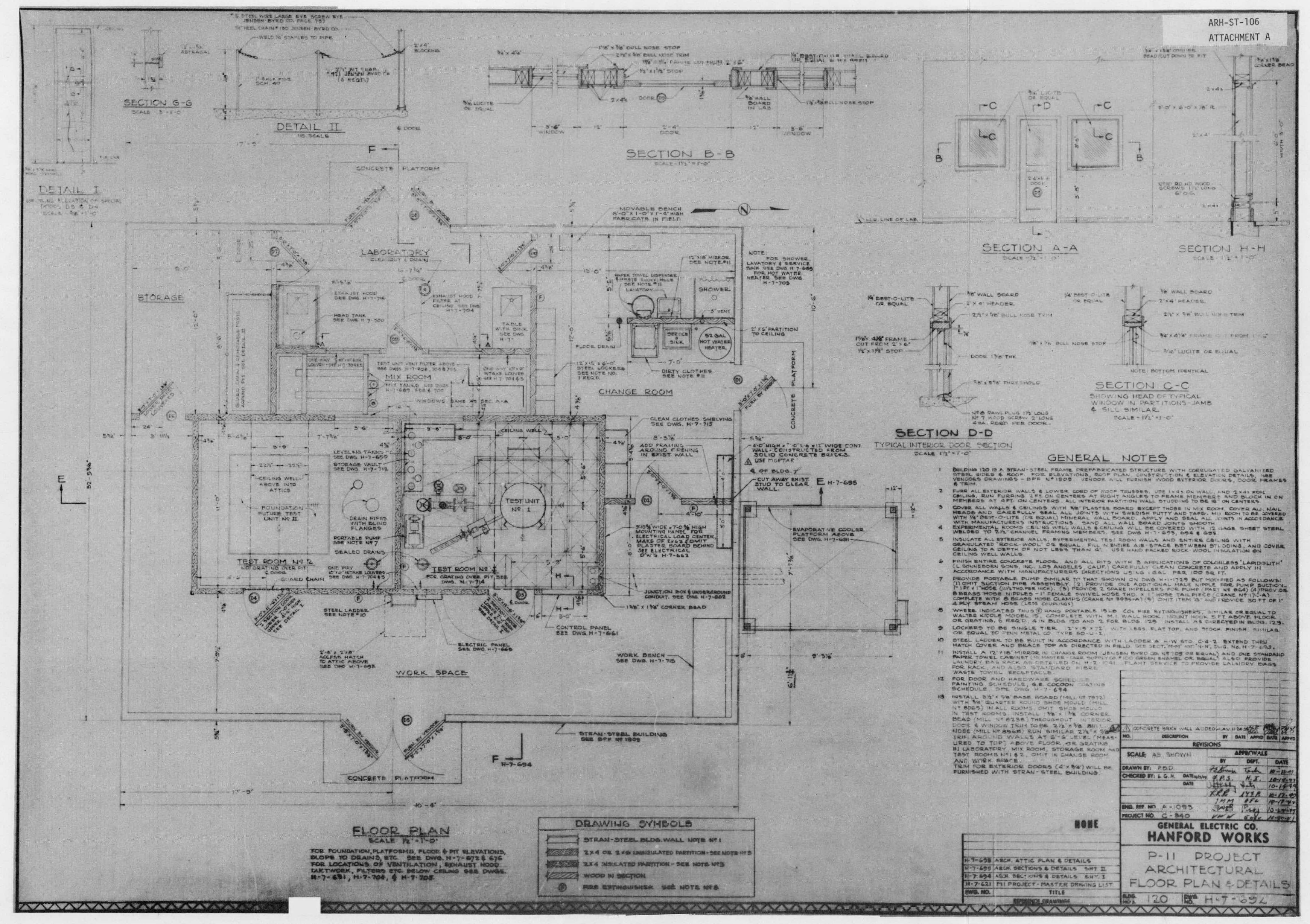


P-11 FACILITTY CLEANUP

ORGANIZATIONAL CHART

RESPONSIBILITIES \& AUTHORITY

(REFERENCE: WORK PROCEDURE DATED FEBRUARY 22, 1974)

ARH-ST- 106

Attachment

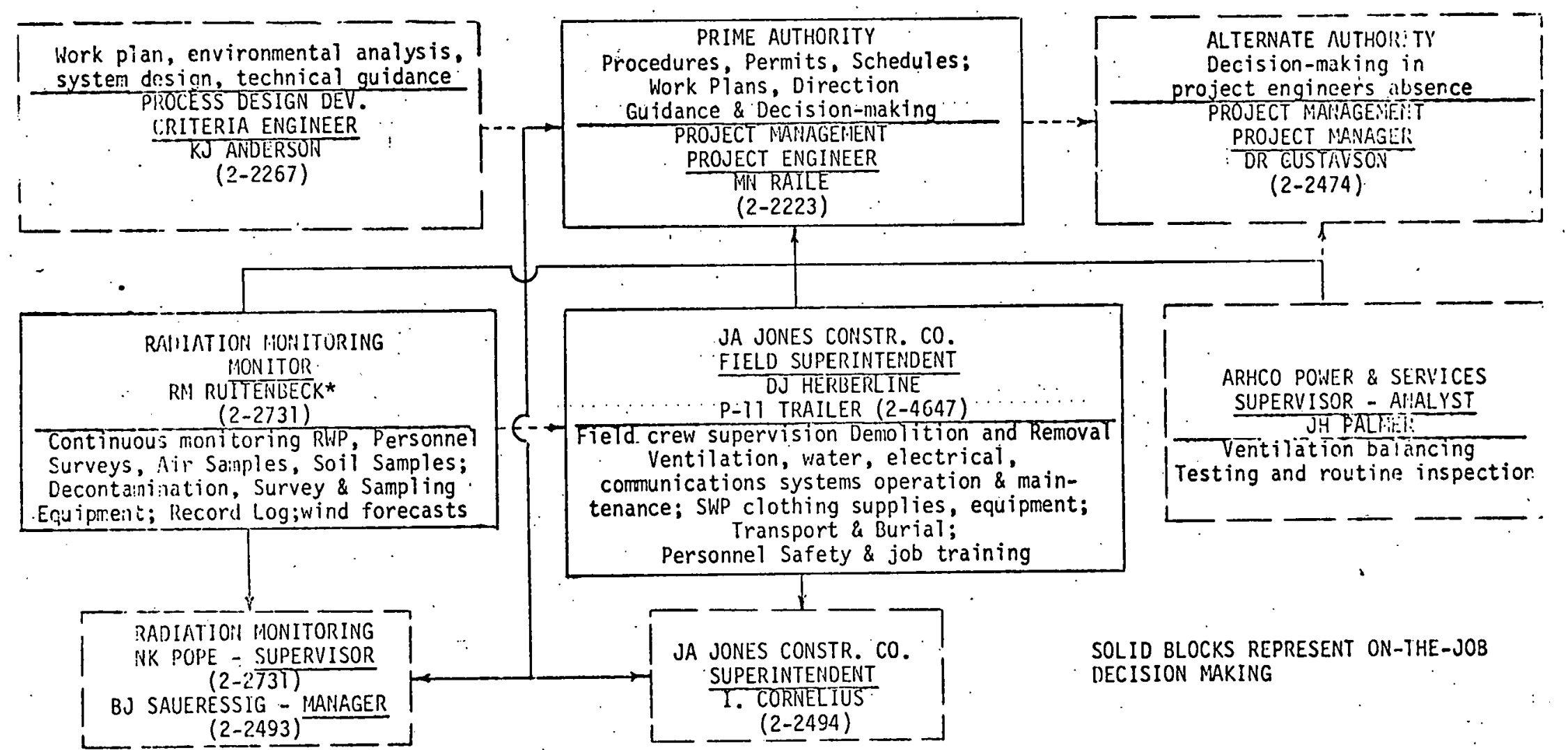

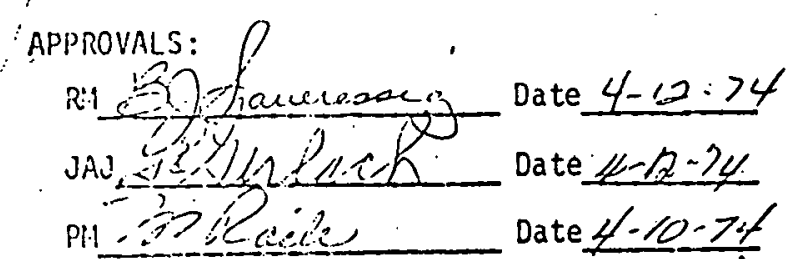

Min:sic.
*Will represent project engineer on routine matters in project engineer's absence. Must contact and obtain approval from project engineer (or alternate) on any decision-making matters or deviations from established procedures or plans.

Authority is to be exercised through JA Jones supervision. Piay stop work without project engineer's approval whenever radioactive conranination or unsafe conditions warrant such action. 


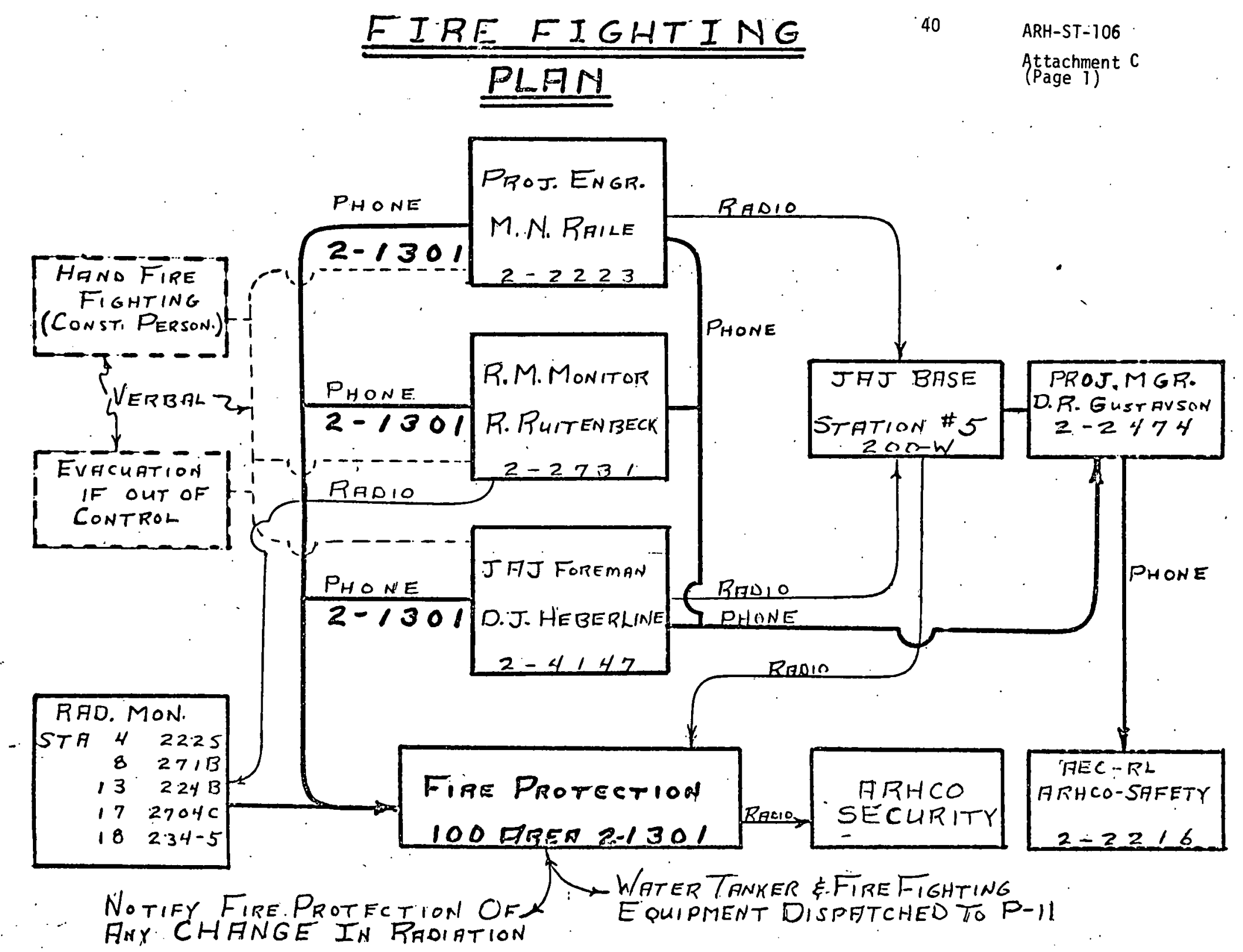


FIRE PLAN PROCEDURE

41

ARH-ST-106

Attachment $C$

(Page 2).

- Project Engineer, R.M. Monitor. or JAJ Foreman, to initiate FiRE PlAN. by PHONE (From 2-4147), CALL" FIRE PROTECTION 2-1301"

ia* Project Engineer, RiMini. Monitor or JAJ. Foreman, to initiate FirE PLON by RADIO - CALL" JAJ BASE STATION \#5-200W"

2 Project Engineer, R. Mi Monitor or JHJ Foreman to instruct Construction personnel to fight fire using extinguishers:

A. Water filled type for WOOD, PAPER or TEXTILES. B. Dry Chemical type for ELECTRICAL or Or.

3 If fire cannot be extinguished by hand means, responsible Supervisor is to instruct all workers to evacuate $p$-ll area.

4 All personnel are to evacuate to outside of perimeter fence until fire fighting equipment arrives and clears the area for re-entiy.

* Life this procedure mn 4-3.24

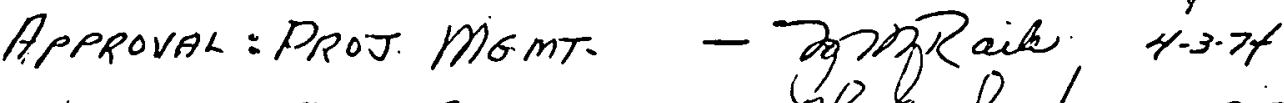

TAJ Canst. Co. - DlDeslach 4.-3.3x Fire Protection - " ci lieut

RAMoN. - BgAamiesain 
Attachment D

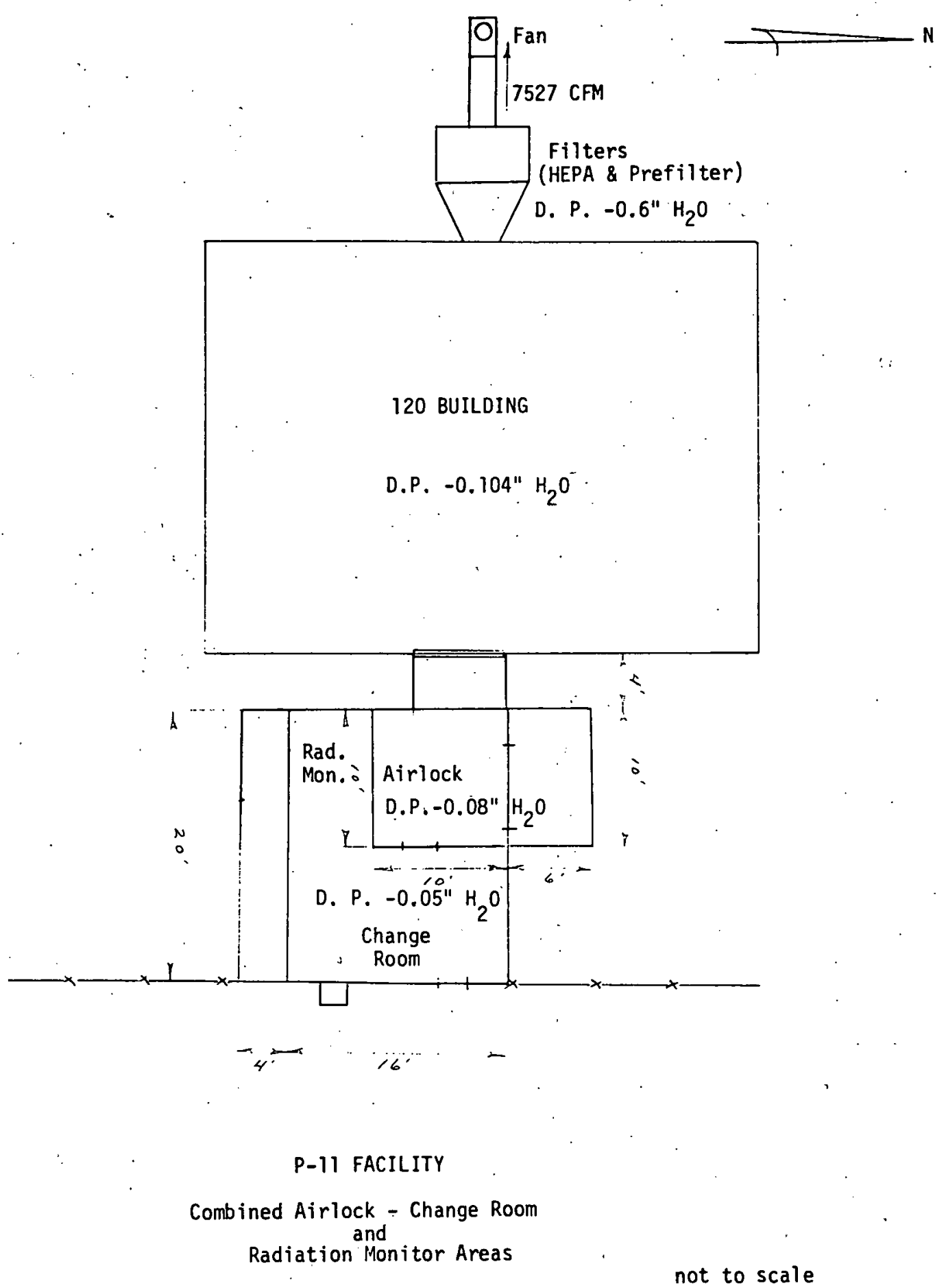




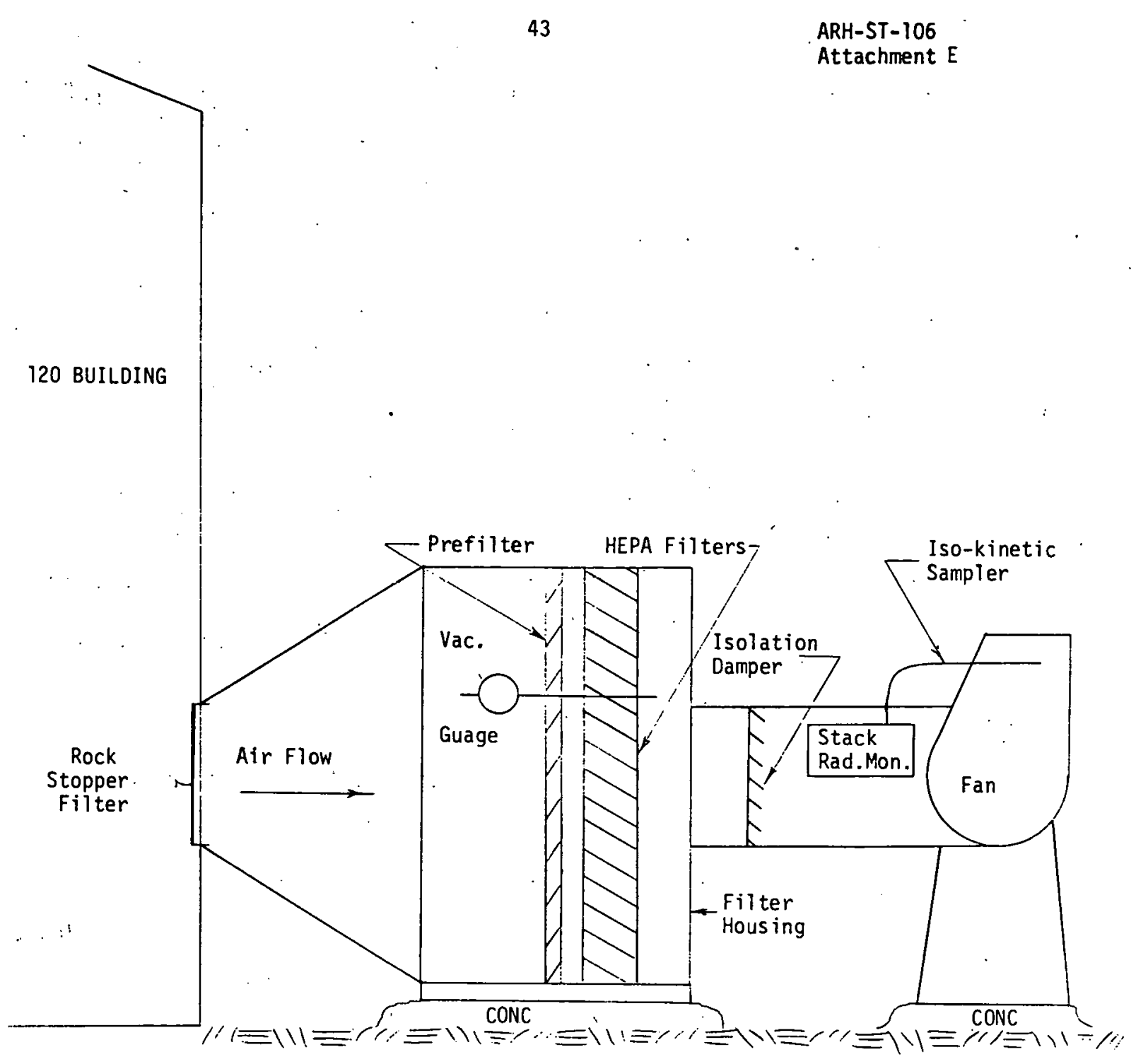

P-11 FACILITY

VENTILATION-FILTRATION EQUIPMENT 
DISTRIBUTION

\section{Atomic Energy Commission, Headquarters}

F. D. Baronowski

R. G. Heusser

\section{Atomic Energy Commission, Richland Operations Office}

0. J. Elgert (5)

G. M. Granere

P. G. Rhoades

D. M. Smith

H. D. Smith

J. H. Straub

\section{Atomic Energy Commission, Oak Ridge, Tennessee}

Technical Information Center (189)

Battelle Northwest

E. D. Clayton

K. M. Harmon

K. L. Kipp

J. A. Jones Construction Company

J. P. Bennett

I. Cornelius

M. L. Marlin

Vitro Engineering, Division of Automation Industries, Inc.

D. R. Nelson

L.-J. Prues

\section{Atlantic Richfield Hanford Company}
J. D. Anderson
H. H. Hopkins, Jr.
R. M. Ruitenbeck
G. E. Backman
L. C. Hubbard
C. M. Salina
L. D. Bockstanz
W. P. Ingalls
B. J. Saueressig
D. E. Braden
R. E. Isaacson
H. P. Shaw
G. Burton, Jr.
J. W. Jordan
R. M. Smi thers
J. H. Davis
C. W. Malody
G. T. Stocking
N. C. Dresser
H. L. Maxfield
J. H. Warren
J. Faulhaber
B. J. McMurray, Sr.
J. B. Fecht
R. E. Felt
D. C. Nelson
G. A. Nicholson
L. W. Finch
G. C. Oberg
D. R. Gustavson
N. K. Pope
W. M. Harty
M. N. Rajle
G. 0 . Wheeler
D. D. Wodrich
Central File
ARHCO Document Service (2)
Extra (3) 